\title{
Scenarios for earthquake-generated tsunamis on a complex tectonic area of diffuse deformation and low velocity: The Alboran Sea, Western Mediterranean
}

\author{
José A. Álvarez-Gómez , Î̃̃igo Aniel-Quiroga , Mauricio González , \\ Maitane Olabarrieta , Emilio Carreñc \\ anstituto de Hidráulic Ambiental "IH Cantabria", Universidad de Cantabria, E.T.S.I de Caminos, Canales y Puertos, Av. de los Castros, s/n, 39005 Santander, Spain \\ b Departamento de Geodinámica, Facuitad de Geología, Universidad Complutense de Madrid, C/ José Antonio Novais, s/n, 28040, Madrid, Spain \\ ' U.S. Geological Survey, Woods Hole Coastal and Marine Science Center, 384 Woods Hole Road, Woods Hole, MA 02543, United States \\ 'Instituto Geográfico Nacional, C/ General Ibañez Ibero, 3, 28003, Madrid, Spain
}

Keywords:

Alboran Sea

Western Mediterranean

tsunami hazard

Carboneras Fault

Alboran Ridge

Yusuf Fault

\begin{abstract}
A B S T R A C T
The tsunami impact on the Spanish and North African coasts of the Alboran Sea generated by several reliable seismic tsunamigenic sources in this area was modeled. The tectonic setting is complex and a study of the potential sources from geological data is basic to obtain probable source characteristics. The tectonic structures considered in this study as potentially tsunamigenic are: the Alboran Ridge associated structures, the Carboneras Fault Zone and the Yusuf Fault Zone. We characterized 12 probable tsunamigenic seismic sources in the Alboran Basin based on the results of recent oceanographical studies. The strain rate in the area is low and therefore its seismicity is moderate and cannot be used to infer characteristics of the major seismic sources. These sources have been used as input for the numerical simulation of the wave propagation, based on the solution of the nonlinear shallow water equations through a finite-difference technique. We calculated the Maximum Wave Elevations, and Tsunami Travel Times using the numerical simulations. The results are shown as maps and profiles along the Spanish and African coasts. The sources associated with the Alboran Ridge show the maximum potential to generate damaging tsunamis, with maximum wave elevations in front of the coast exceeding $1.5 \mathrm{~m}$. The Carboneras and Yusuf faults are not capable of generating disastrous tsunamis on their own, although their proximity to the coast could trigger landslides and associated sea disturbances. The areas which are more exposed to the impact of tsunamis generated in the Alboran Sea are the Spanish coast between Malaga and Adra, and the African coast between Alhoceima and Melilla.
\end{abstract}

\section{Introduction}

The Alboran Sea is located on the western end of the Mediterranean Sea. Tectonically, the Alboran Basin is a complex zone that is being squeezed between the approaching Iberian and African plates. This convergence between the two main plates deforms the Alboran thinned crust, forming a set of conjugate shear zones and transpressive structures, including reverse faults, active since the Late Tortonian (Iarouzière et al., 1988; Bourgois et al., 1992; Comas et al., 1992; Vegas, 1992; Woodside and Maldonado, 1992; Watts et al., 1993; Martínez-Díaz, 2002; Masana et al., 2004; Gràcia et al., 2006). Although the rate of deformation is low, approximately $4.7 \mathrm{~mm} /$ year (McClusky et al., 2003; Stich et al., 2006; Serpelloni et al., 2007), the geomorphological and geophysical data show evidences of recent ruptures and faults large enough to generate great earthquakes (Gràcia et al., 2006; Mauffret et al., 2007; Ballesteros et al., 2008; Maestro-González et al., 2008).

This area has suffered in the past several tsunamis, the main part of them with little impact, although damages to harbors and coastal inundations have been described (Soloviev et al., 2000; IGN, 2009b). The margins of the Alboran Sea are very developed areas, with increasing population and key to the tourism sector of the western Mediterranean, whether consolidated, such as the Spanish coast or emerging such as the North African. The recent experience of the 2003 Boumerdes-Zemmouri earthquake and tsunami has shown that even moderate events can produce sea waves with enough energy to cause significant economic losses. Tsunamis in the Alboran coast are historically more frequent than in the Balearic (IGN, 2009b), and given that the population and industrial development are higher in this area, an evaluation of the tsunami hazard seems necessary.

Our approximation to the study of the tsunami hazard in the area is based on the generation of worst case scenarios. This deterministic approach supplies information of the expected tsunami impact along 
the Alboran Sea Margins based on realistic assumptions of fault ruptures. González et al. (2010) studied the same area although the approximation to the problem in that case was different, a probabilistic method was used and the sources used were not based on the most recently published geological and geophysical data (Gràcia et al., 2006; Mauffret et al., 2007; Ballesteros et al., 2008; Maestro-González et al., 2008).

Within the framework of the European Research Project TRANSFER (Tsunami Risk ANd Strategies for the European Region; http:// labtinti4.df.unibo.it/transfer/) the tectonic structures capable of generating tsunamigenic earthquakes in the Alboran Basin were compiled. The probable fault ruptures were characterized based on these structures to be used as sources for the generation of numerical models of wave propagation. These models allowed us to determine the most exposed areas to the tsunami hazard and can be of use to the civil protection agencies, land-use planners and tsunami warning system development.

The results are shown as maps of Maximum Wave Elevation and Tsunami Travel Time, and Wave Elevation Profiles along the coast. A total of 12 individual and composed sources have been modeled.

\section{Tectonic setting}

The Alboran Sea is located between the Betic range (southern Spain) and the Rif (northern Morocco) (Fig. 1). There is debate on the nature of its crust. The existence of oceanic crust or thinned continental crust in the Alboran Sea has important implications for tsunami generation models.

The crust characteristics control basic parameters of the elastic models of fault deformation: maximum depth of the fault, stiffness and displacement-stress-drop relation for the earthquake generated. The maximum depth of failure will determine the width of the fault plane and therefore the area of the rupture. The rupture area, along with the stiffness and the mean displacement along the fault at an event provides the seismic moment and magnitude. Moreover the nature of the crust determines the type of empirical relationship which can be used; the Wells and Coppersmith (1994) relation being valid only for the continental crust.

Regarding the depth, there is a reasonable consensus on the thinned character of the crust in this area (Comas and Soto, 1999; Torne et al., 2000; López Casado et al., 2001; Faccenna et al., 2004; Booth-Rea et al., 2007; Díaz and Gallart, 2009). Díaz and Gallart (2009) propose a crustal thinning related to large extensional tectonics affecting the area, which agrees with previous observations of thinning from a crustal thickness of $35-40 \mathrm{~km}$ in the Betic Chain to about $15-20 \mathrm{~km}$ beneath the central Alboran Sea (Comas and Soto, 1999; Torne et al., 2000; López Casado et al., 2001). Booth-Rea et al. (2007) reach similar conclusions based on the study of deep seismic profiles. This thinning has implications for the seismogenic depth and therefore the maximum width of the fault. López Casado et al. (2001) clearly show the almost exclusive presence of shallow seismic events $(<15 \mathrm{~km})$ in the Alboran domain, ignoring the deeper earthquakes related to the Arc of Gibraltar, and not related to the deformation of the Alboran domain. These shallow depths are typical of earthquakes occurring on the continental crust; in the oceanic crust the events often reach depths of up to $40-50 \mathrm{~km}$ (Watts and Burov, 2003), such as in the Gulf of Cadiz, with oceanic crust and involving the elastic deformation of the lithospheric mantle Stich et al. (2005).

Regarding the nature of the crust of the Alborán basin, for Torne et al. (2000) there is no doubt: "there is no evidence for the existence of Cenozoic oceanic lithosphere in the Betic-Rif-Alboran region" and "the basement of the Alboran Basin is formed primarily of metamorphic complexes belonging to the Alboran crustal domain." However, it is true that towards the eastern part of the basin, entering in the Algero-

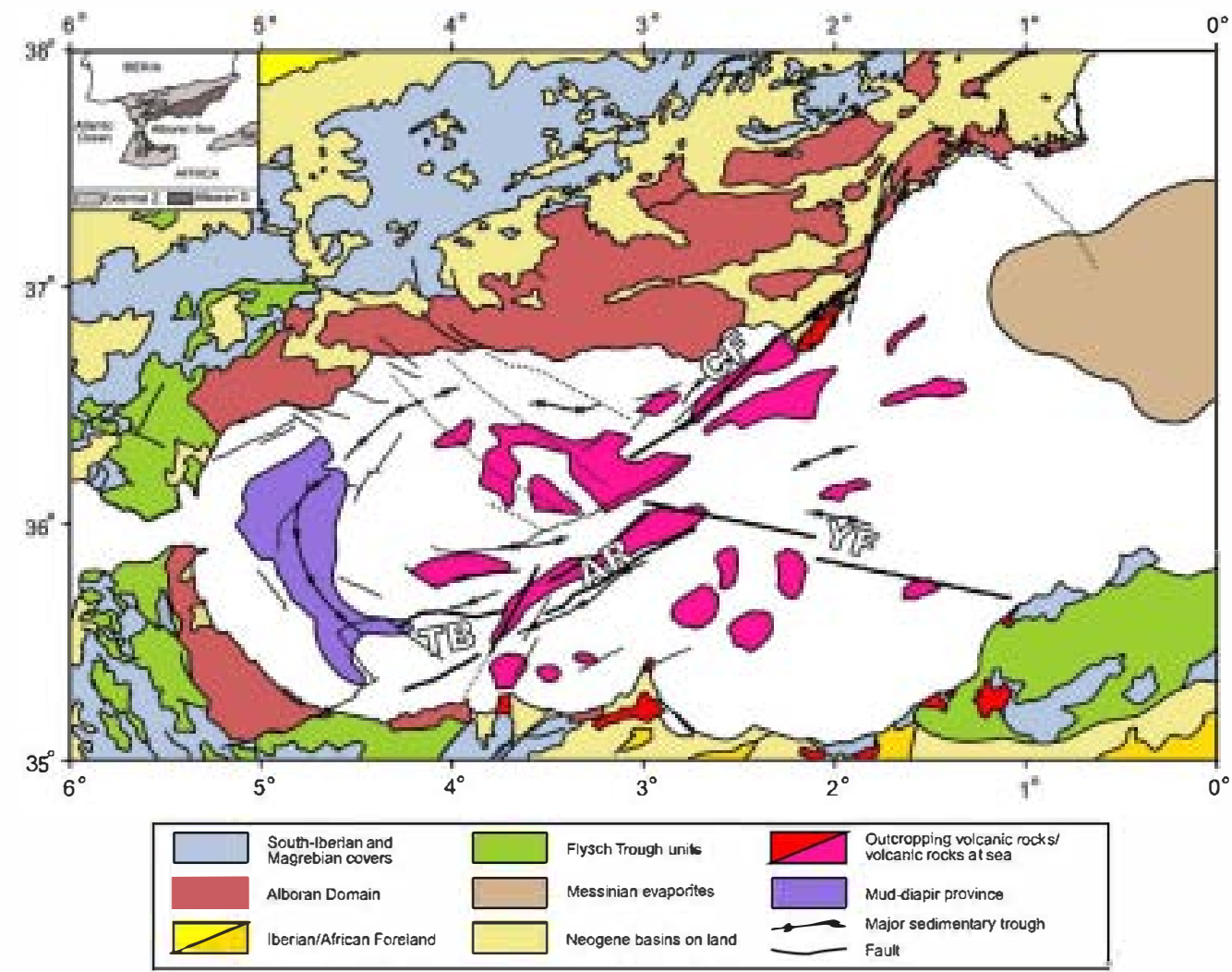

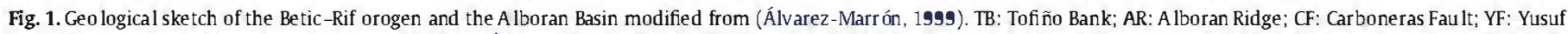

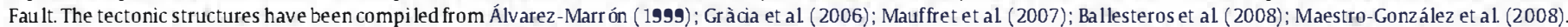


Balearic basin, the characteristics of the crust are more increasingly of the oceanic type (Booth-Rea et al., 2007) although all the tsunamigenic structures discussed in this work are clearly developing in the central-western basin, with characteristics essentially of thinned continental crust as described by Booth-Rea et al. (2007). This thinned crust has been intruded by magmatic complexes in the Miocene, although it does not present purely oceanic crust characteristics but immature oceanic arcs developed on continental crust.

The structural configuration of the Alboran Basin and its evolution is complex and is a subject of debate. That which seems to be clear is the huge displacement of this crustal domain from an eastward position towards its actual location during the Neogene. Different processes have been proposed to explain this evolution and the thinning of the crust: westward displacement due to the opening of the Algero-Provençal Basin (Sanz de Galdeano, 1990); subduction of Africa under Iberia, being the Alboran Basin a back-arc basin (Morley, 1993); subduction of Iberia under the Betic Cordillera and the Alboran Basin (Morales et al., 1999); east dipping subduction of the Atlantic, Iberia and Africa under the Alboran domain (Royden, 1993; Lonergan and White, 1997); and thinning of the crust due to convection processes in the mantle (Weijermars, 1985; Doblas and Oyarzun, 1989; Platt and Vissers, 1989; Vissers et al., 1995). In addition to these hypotheses to explain the shallow tectonics, there are also a number of hypotheses to explain the intermediate and deep focus earthquakes that take place in the area, divided into delamination processes (García-Dueñas et al., 1992; Watts et al., 1993; Docherty and Banda, 1995; Seber et al., 1996; Buforn et al., 1997; Mezcua and Rueda, 1997; Morales et al., 1997) and subducted slab processes (Royden, 1993; Gutscher et al., 2002; Thiebot and Gutscher, 2006); maybe being both active for deep and intermediate earthquakes respectively (Buforn et al., 1991; López Casado et al., 2001).

The active tectonics of the Alboran Basin is mainly characterized by the relevant strike-slip fault systems. This strike-slip faulting is active since at least late Tortonian times (7-9 Ma) (Bourgois et al., 1992; Comas et al., 1992; Woodside and Maldonado, 1992) during which the Alboran Basin was broken into sub-basins divided by transverse volcanic ridges. Two families of conjugate strike-slip fault systems are active in the Alboran Basin. These structures have been interpreted as a pure shear deformation mechanism due to the NNW-SSE convergence of Iberia and Africa (Vegas, 1992). The main branches of this conjugate system are the left-lateral system that runs from Almeria in southeastern Spain towards El Jebha in northern Morocco and the right-lateral system runs from northern Algeria to Malaga, in southern Spain. The former is composed basically by the Carboneras Fault (CF in Fig. 1) and the faults belonging to the Alboran Ridge (AR in Fig. 1), this shear zone is known as the Trans-Alboran Shear Zone (TASZ) (Larouzière et al., 1988; Fernández-Ibáñez et al., 2007). The main structure of the right-lateral system is the Yusuf Fault (YF in Fig. 1). The TASZ has been interpreted as a major block boundary which nucleates the deformation and varies the stress tensor orientation on its surroundings (Fernández-Ibáñez et al., 2007). The NE-SW trending structures have been described as transpressive, being mainly leftlateral with thrust component (Bourgois et al., 1992; Watts et al., 1993; Martínez-Díaz, 2002; Booth-Rea et al., 2004; Masana et al., 2004; Gràcia et al., 2006), while the WNW-ESE structures are mainly right-lateral presenting normal dip-slip components in some areas (Âlvarez-Marrón, 1999).

In accordance with this complex tectonic setting, the seismicity of the area is varied and scattered (Fig. 2), with small to moderate earthquakes and focal mechanisms ranging from pure thrust to strikeslip and oblique with normal component (Figs. 4 and 5). The seismicity of the zone is characterized by its shallow depth (Fig. 3), except in the Gibraltar Arc (Fig. 2), where a band of intermediate to deep seismicity with north-south direction appears. These intermediate to deep events seem to be related with the existence of a lithospheric slab under the western part of the Alboran domain. This intermediate seismicity is not a probable cause of sea bottom deformation in the Alboran Basin and therefore is not considered in this study.

A reasonable lower limit for the shallow seismogenic zone in the Alboran Domain is around $10-12 \mathrm{~km}$, where a major part of the seismicity is concentrated (Fig. 3). This shallow lower limit is in agreement with the lithospheric structure obtained from geophysical and rheological modeling (Docherty and Banda, 1995; Torne et al., 2000; Fullea et al., 2007; Fernández-lbáñez and Soto, 2008) and from previous seismicity studies (López Casado et al., 2001). This thin crust implies a physical limit to the generation of great earthquakes, although some important events have been described in historical times with intensities of VIII-IX and estimated magnitudes of 6.5-7.0 (Martínez Solares, 2003; IGN, 2008).

Another element which proves the complexity of the area is the varied character of the focal mechanisms. In Fig. 4 the focal mechanisms for the area from the IGN (2009a) and Stich et al. (2003) catalogs are shown. Many of the focal mechanisms in the Alboran Basin show strike-slip character with dip-slip component; while the events situated onshore show normal and reverse character. In Fig. 5 these events are represented in a classification diagram (Álvarez Gómez, 2009) modified from the one proposed by Kagan (2005) based on the geometrical representation of Kaverina et al. (1996). The earthquakes situated offshore (represented as filled circles) are projected mainly on the fields of strike-slip-normal character, but on the field of reverse character too, although to a lesser extent. Great part of the events seems to be related to the structures that forms the TASZ: the Alboran Ridge and the Carboneras Fault.

As shown in Fig. 5 most of the events have magnitudes less than 5 , which means that they have been generated by fractures of small size. If we use the empirical relationships of Wells and Coppersmith (1994) we can see that $a M_{W} \approx 5$ event is generated by a fault with a subsurface rupture length of around $2 \mathrm{~km}$. The focal mechanisms that we have in this area mostly represent fractures of hundreds of meters and release energies so low that they cannot be considered representative of the seismic cycle of large tsunamigenic structures.

These small events cannot therefore be used to characterize the sources, they are only of use to show the tectonic complexity of the area. Moreover, the strength of the faults is greater in the case of reverse faulting events (Scholz, 2002) than in that of normal events due to the rheology of rocks. This means that while the reverse events can release more energy and generate greater earthquakes, they are also less common, while the normal fault events are more frequent and smaller in magnitude. The tensile strength of faults and rocks is much smaller than the compressive strength, especially in shallow areas of the crust.

In addition to this inherent characteristic of the methodology of seismotectonics, the uncertainty of the focal mechanism calculus with such small sized events is not negligible. Although in the case of large earthquakes the results obtained by different seismic networks are very similar (though rarely identical), in the case of small earthquakes the uncertainty and error make the results of different networks sometimes inconsistent from a tectonic point of view.

\section{Sources characterization}

In order to characterize the potential seismic tsunamigenic sources from a deterministic point of view, the geometric characteristics of the faults, and the expected amount of slip for a worst case earthquake must be defined. The maximum surface rupture can be approximated from the known fault traces, imposing a maximum size for the earthquake based on geomorphological observations. In the last years a number of oceanographical surveys, in addition to a compilation of previous data, have led to the definition of different structures by various authors (Gràcia et al., 2006; Mauffret et al., 2007; Ballesteros et al., 2008; Maestro-González et al., 2008); these results have been 


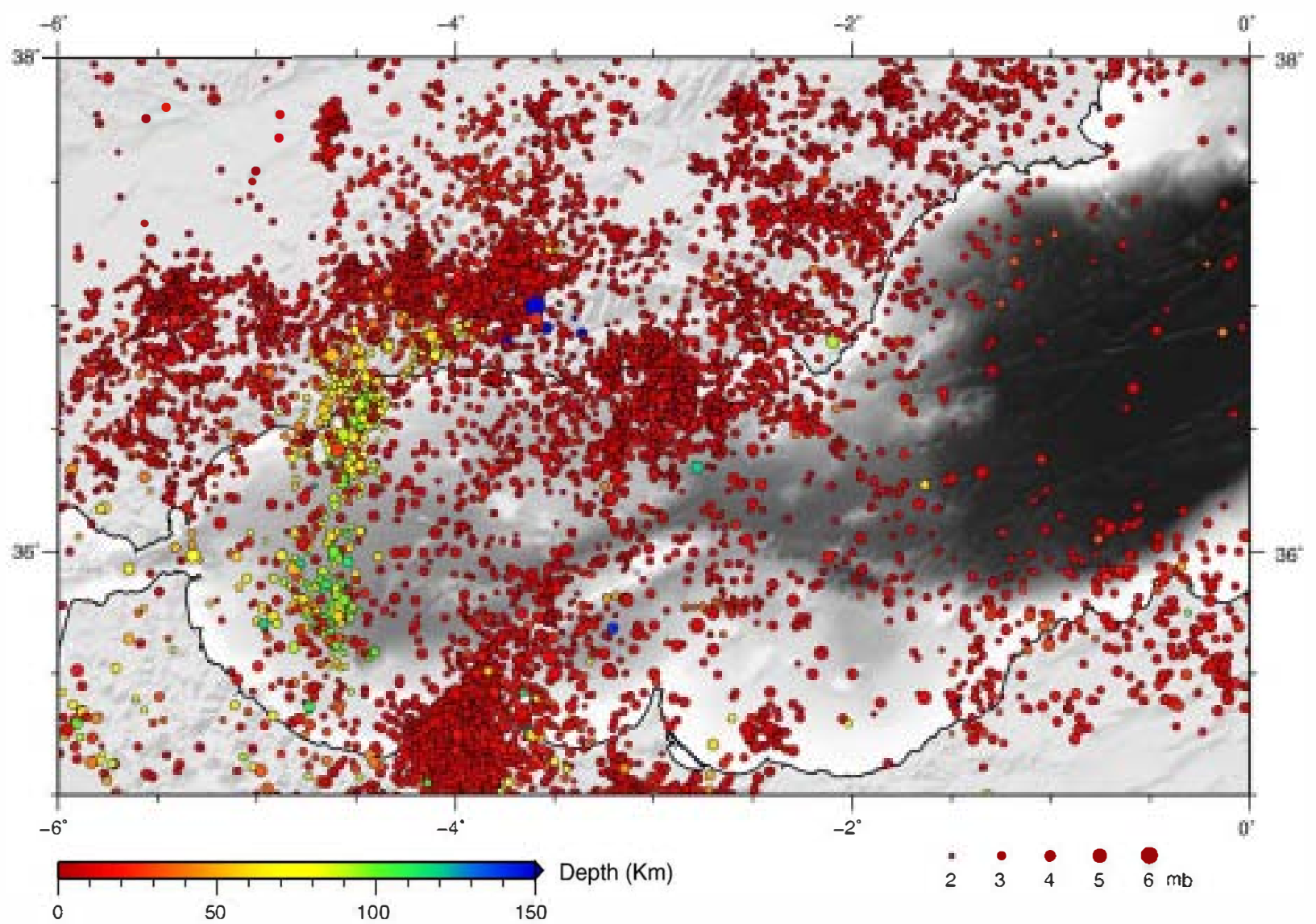

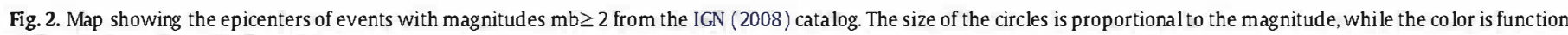
of the depth, as shown in the scale.

used to define the fault's segmentation and rupture lengths (Fig. 6). For the maximum depth, and consequently for the width of the fault we have estimated the maximum seismogenic depth based on the distribution of earthquakes and from the bibliography discussed in the previous section. For the Yusuf Fault the maximum depth is shallower due to the progressive thinning of the crust towards the east. The dip and rake of the faults have been obtained from the bibliography when possible. When not available, the values were estimated taking into account the tectonic setting and the typical rupture characteristics of similar faults.

\subsection{Alboran Ridge}

The Alboran Ridge is bound to the northwest and to the southeast by steep faults that form positive flower-like left-lateral strike-slip structures. The northern fault dips slightly towards the southeast while the southern fault dips slightly towards the northwest (Estrada et al., 1997). Ballesteros et al. (2008) proposed that the northeastem fault of the Alboran Ridge is connected in some way with the SerrataCarboneras Fault, supporting the hypothesis of Maldonado et al. (1992) and Woodside and Maldonado (1992). Some of the secondary structures seem to be reverse faults that fold the overlaying sediments (Álvarez-Marrón, 1999). Other authors also describe compressional structures on both sides of the Alboran Ridge (Woodside and Maldonado, 1992; Watts et al., 1993). The estimated uplift of the Alboran Ridge is $750 \mathrm{~m}$ relative to the Alboran Basin (Campos et al., 1992). A northwest-dipping fault with reverse component in the southern flank coincides with the Jebha left-lateral strike-slip fault inland (Meghraoui et al., 1996; Morel and Meghraoui, 1996), this structure being proposed as the onshore continuation of the offshore structures (Maestro-González et al., 2008). In a similar way Mauffret et al. (2007) interpret the presence of the Tofiño Bank and the Xauen
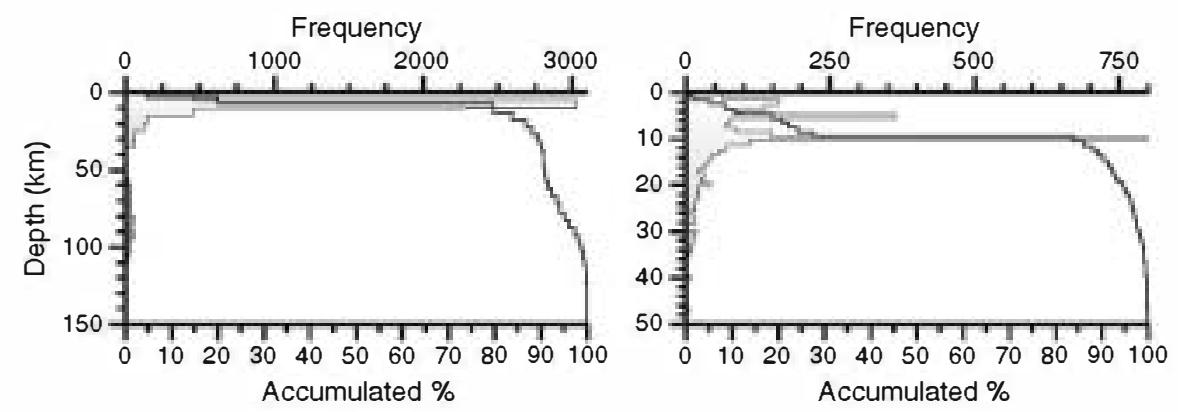

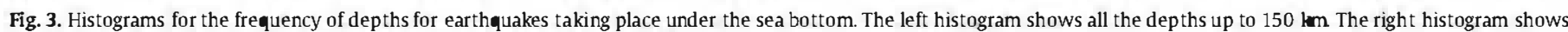
the shallow seismicity. Thick lines show accumulated frequencies as percentages. 

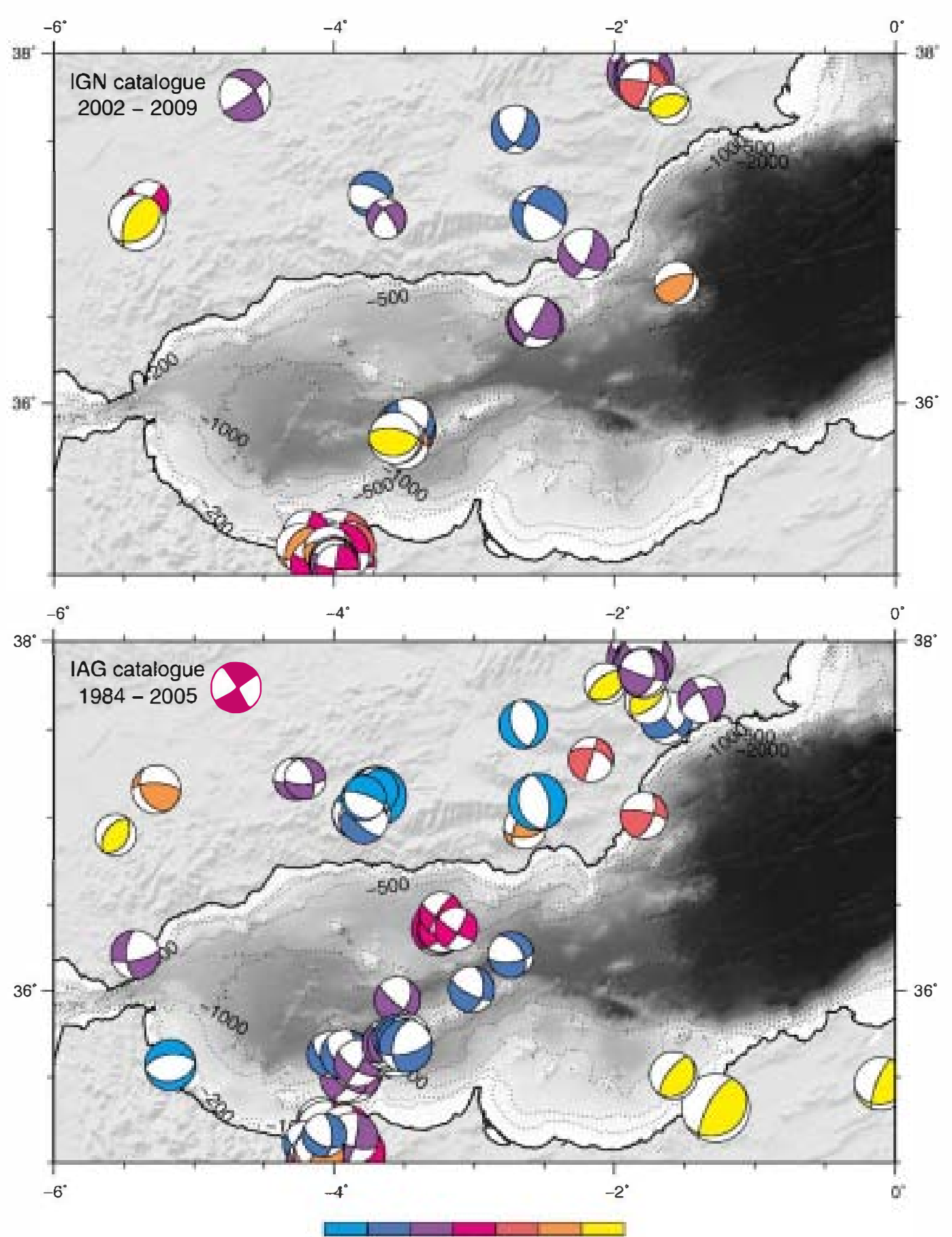

N NS SN S SR RS R

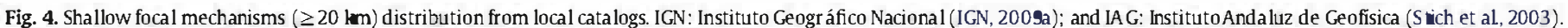

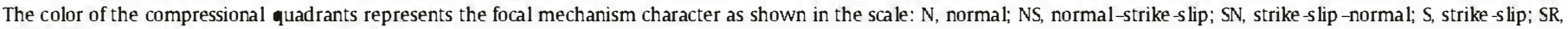
strike-slip-reverse; RS, reverse-strike-slip; $R$, reverse.

Bank as morphological expressions of mainly reverse structures on the southern edge of the Alboran Ridge.

We model the Alboran Ridge as a "pop-up" like structure, associated to a positive flower strike-slip structure, with the faults of the northern and southern flanks dipping towards the south and north respectively, uplifting the ridge with important reverse component. The southern flank of the ridge is composed of two segments with similar characteristics, high dip and mainly reverse slip; the "Alboran Ridge Southern Fault East" (ARSFE) and "Alboran
Ridge Southern Fault West" (ARSFW). The northern flank is composed of three faults with different characteristics. The eastern segment is subparallel to the southern flank faults, presenting oblique slip, we named it here as the "Alboran Ridge Northern Fault East" (ARNFE). The middle segment, the "Alboran Ridge Northern fault West" (ARNFW), has a NNE-SSW direction with higher dip and mainly strike-slip motion. Finally, at the southern edge we model the "Tofiño Bank Fault" (TBF), a mainly reverse fault uplifting the Tofiño Bank (Mauffret et al., 2007). 


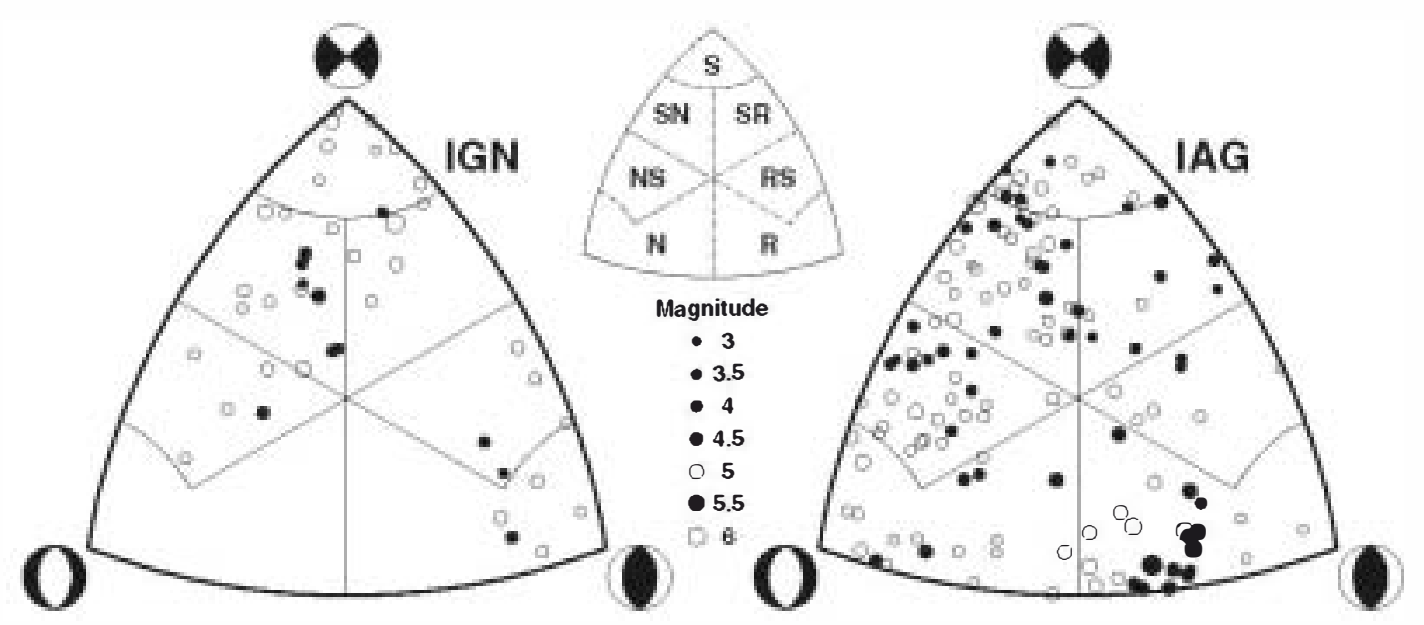

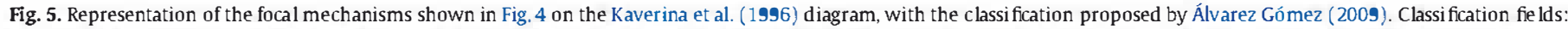

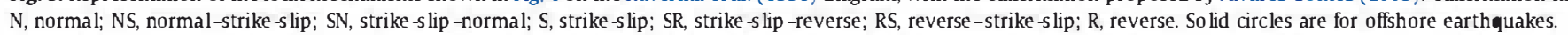

\subsection{Carboneras Fault}

The Carboneras Fault (also known as Serrata Fault or SerrataCarboneras Fault) is a NE-SW active structure that forms the northwestern boundary of the volcanic complex of Cabo de Gata (Pineda Velasco et al., 1978). The trace of this fault is clear onshore and also offshore, mainly presenting left-lateral strike-slip character but with a dip slip component too (Pineda Velasco et al., 1978; Gràcia et al., 2006; Ballesteros et al., 2008). The length of the fault offshore is greater than $70 \mathrm{~km}$ (Gràcia et al., 2006) having at the present stage some reverse component (Estrada et al., 1997; Gràcia et al., 2006) that downthrows the northwestern block (Ballesteros et al., 2008). Bell et al. (1997) propose a main reverse component of the fault in recent times, with an uplift rate of $0.05-1 \mathrm{~mm} /$ year for the last $100 \mathrm{ka}$; although the offshore shows a positive flower structure indicating the basically strike-slip component (Estrada et al., 1997) being active at least since Messinian times (Woodside and Maldonado, 1992; Rodríguez and Martin, 1993; Watts et al., 1993; Estrada et al., 1997). Some authors point to this fault as the source of the 1522 Almeria earthquake, which caused seafloor rupture and coastal flooding (Gràcia et al., 2006; Reicherter and Hübscher, 2007).

The fault offshore is divided into two main segments with slightly different strike and morphological expressions (Gràcia et al., 2006): a north segment, $33 \mathrm{~km}$ long, dipping towards the southeast and a south segment, $26 \mathrm{~km}$ long, dipping towards the northwest. We have included the onshore segment due to its proximity to the coast, therefore dividing the Carboneras Fault into three segments: the onshore segment, here called "Carboneras Fault Northern" (CFN); the northern offshore segment; "Carboneras Fault Central" (CFC) and the southern offshore segment, "Carboneras Fault Southern" (CFS). The characteristics of the onshore segment are very similar to those of the northern offshore segment (Keller et al., 1995; Gràcia et al., 2006; Moreno et al., 2008).

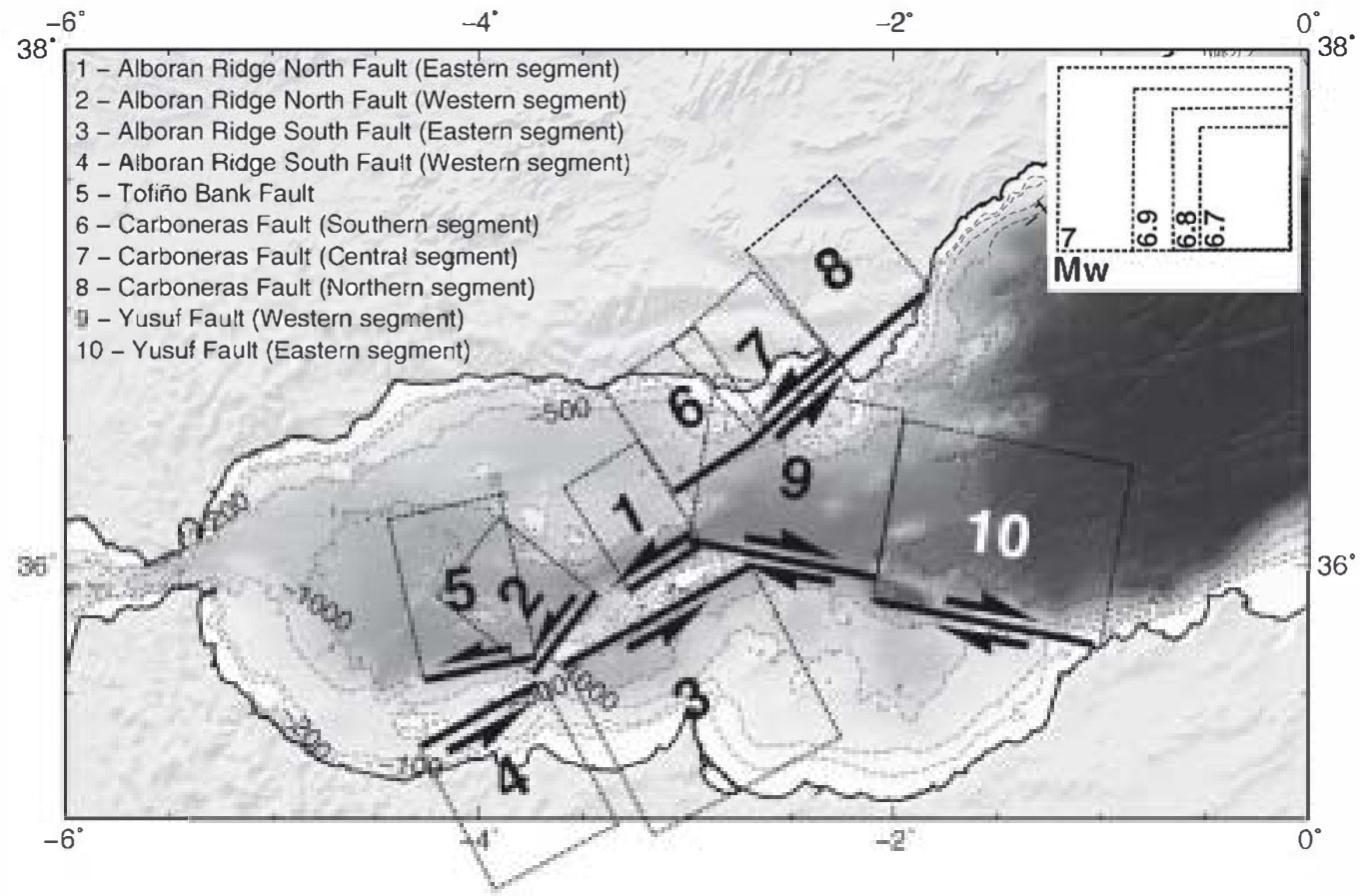

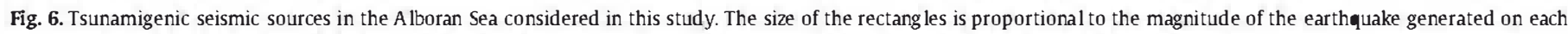
segment; its position in the figure is in interest of a clearer representation and is not related to any geometric parameter of the source. 
Due to the clear continuity of this fault, we decided to model not only the three segments described above, but the combination of the two northern segments and the three fault segments at the same time to take into account the worst cases.

\subsection{Yusuf Fault Zone}

The Yusuf Fault Zone is a right lateral strike-slip fault system made up of two branches in right step over that forms an elongated rhombshaped pull-apart basin (Mauffret et al., 1987; Álvarez-Marrón, 1999). The Yusuf Fault shows an apparent vertical throw of at least $2000 \mathrm{~m}$ (Álvarez-Marrón, 1999) and forms negative flower structures into a transtensive regime (Estrada et al., 1997). Mauffret et al. (1987) also suggested a horizontal displacement for the Yusuf Fault of $30-35 \mathrm{~km}$ based on the distribution of magnetic anomalies and the basin morphology. If we assume a coeval evolution of both deformation components, a rake of $176^{\circ}$ is obtained for an idealized sub-vertical fault. The rate of deformation of this fault seems to be decreasing since the first stages of the Quaternary until recent times (Estrada et al., 1997).

We model the Yusuf Fault Zone as a right-lateral strike-slip structure formed by two clear segments forming a right step-over. The northern side of the structure is downthrown and a pull apart basin is formed in the transition between the two branches. These two segments are referred to as "Yusuf Fault Western" (YFW) and "Yusuf Fault Eastern" (YFE).

\subsection{Rupture parameters}

Being the main character of the faults in the Alboran Basin strikeslip, and although thinned, the crust can be considered of continental affinity (Torne et al., 2000), we have used the Wells and Coppersmith (1994) empirical relations to define the expected maximum magnitude. From the length of the fault trace we obtained the $M_{W}$ magnitude; and the average rupture displacement over the fault from the moment magnitude definition (Kanamori and Anderson, 1975; Kanamori, 1977):

$\log \mathrm{M}_{\bullet}=\frac{3}{2} \mathrm{M}_{\mathrm{W}}+11.8$

$\mathrm{M}_{\bullet}=\mu S \bar{D}$

being $\mathrm{M}_{0}$ the seismic moment, $\mu$ the shear modulus, $S$ the rupture area and $\bar{D}$ the average displacement over the fault. We have considered the maximum depth of the rupture as $11 \mathrm{~km}$, except for the Yusuf Fault, in which the maximum depth has been taken as $10 \mathrm{~km}$ dueto its eastward situation.

In Fig. 6 the seismic tsunamigenic sources considered are shown. The size of the earthquake generated by each segment has been represented by the size of the rectangle. In accordance with the historic catalogs, we have obtained maximum earthquake magnitudes $\mathrm{M}_{\mathrm{w}}$ of 6.7-7.2; with average slips of 1-1.9 $\mathrm{m}$ (Table 1 ). The maximum length of individual sources varies from the $37 \mathrm{~km}$ of the smallest rupture (ARNFE) to the $97 \mathrm{~km}$ of the largest one (YFE). If we take into account the composed ruptures, the value of $138 \mathrm{~km}$ for the complete Carboneras Fault (CFS + CFC + CFN) is reached. The width of the faults are similar to the maximum depth of the seismogenic zone due to the high dip common to these mainly strike-slip structures; with the exception of the Tofiño Bank Fault, modeled with more reverse component and smaller dip. In general the rupture parameters are in agreement with the expected maximum earthquake sizes and its geometrical characteristics have been selected to reflect in a simple manner the geological and seismological information available.
Table 1

Faults parameters. ARNFE: Alboran Ridge North Fault Eastern; ARNFW: Alboran Ridge North Fault Western; ARSFE: A lboran Ridge South Fault Eastern; ARSFW: Alboran Ridge South Fault Western; TBF: Tofiño Bank Fault; CFS: Carboneras Fault Southern; CFC: Carboneras Fault Central; CFN: Carboneras Fault Northern; YFW: Yusuf Fault Western; YFE: Yusuf Fault Eastern.

\begin{tabular}{lclrlrll}
\hline Fault & $\mathrm{L}(\mathrm{km})$ & $\mathrm{W}(\mathrm{km})$ & Strike & Dip & Rake & Mw & Slip $(\mathrm{m})$ \\
\hline ARNFE & 37 & 13 & 57 & 60 & 45 & 6.71 & 1.02 \\
ARNFW & 45 & 11 & 38 & 75 & 10 & 6.74 & 1.07 \\
ARSFE & $\mathbf{9}$ & 13 & 242 & 60 & 70 & 7.10 & 1.56 \\
ARSFW & 58 & 13 & 242 & 60 & 70 & 6.91 & 1.32 \\
TBF & 49 & 16 & 78 & 45 & 75 & 6.92 & 1.34 \\
CFS & 42 & 11 & 237 & 85 & 15 & 6.70 & 1.01 \\
CFC & 42 & 11 & 48 & 85 & 15 & 6.70 & 1.01 \\
CFN & 54 & 11 & 50 & 85 & 15 & 6.81 & 1.16 \\
CFC+CFN & 96 & 11 & - & - & - & 7.08 & 1.57 \\
CFS+CFC+CFN & 138 & 11 & - & - & - & 7.24 & 1.9 \\
YFW & 83 & 10 & 101 & 80 & 170 & 6.96 & 1.39 \\
YFE & $\mathbf{9 7}$ & 10 & 282 & 80 & -170 & 7.03 & 1.51 \\
\hline
\end{tabular}

\section{Numerical model}

The model used in the present study is the COMCOT (Cornell Multi-grid Coupled Tsunami) Model. This model is based in the finite difference scheme and has been used to investigate several historical tsunami events in the past: 1960 Chilean tsunami (Liu et al., 1994), 1992 Flores Islands (Indonesia) tsunami (Liu et al., 1995), 2004 Indian Ocean tsunami (Wang and Liu, 2006) and 2003 Algerian tsunami (Wang and Liu, 2005). Additionally, the model has been validated using the benchmark cases proposed in the working frame of the European Tsunami Project TRANSFER (http://labtinti4.df.unibo.it/ transfer/). The initial sea bottom deformation used to start the wave propagation has been computed by means of the Okada (1985) equations from the rupture parameters described above. We assume an almost instantaneous deformation that is fully transmitted to the sea bottom, reported values of rupture velocity over a fault in an earthquake range from 2 to $6 \mathrm{~km} / \mathrm{s}$ (Young et al., 1989; Hartzell and Liu, 1996; Sekiguchi and Iwata, 2002; Umutlu et al., 2004). Considering that the water is uncompressible, this deformation is translated instantaneously into sea surface disturbance.

The model solves both nonlinear and linear shallow water equations, adopting a modified leap-frog scheme. Its nesting capabilities allow simulating tsunami generation and its propagation from the source zone to a given coastal area, considering the possible inundation of coastal zones. In the Mediterranean region, earthquakegenerated tsunamis are expected to present wave lengths between 20 and $5 \mathrm{~km}$ (Wang and Liu, 2005), while maximum water depths are in the order of $3 \mathrm{~km}$. In these circumstances, wave dynamics can be considered mainly horizontal, the vertical accelerations being negligible, hence the pressure field can be assumed to be hydrostatic. The propagation of this kind of waves can be correctly simulated using the shallow water wave equations. In a Cartesian coordinate system these equations can be expressed as:

Mass conservation equation:

$$
\frac{\partial \zeta}{\partial t}+\frac{\partial P}{\partial x}+\frac{\partial Q}{\partial y}=0
$$

Momentum conservation equations:

$$
\begin{aligned}
& \frac{\partial P}{\partial t}+\frac{\partial P^{2}}{\partial x}+\frac{\partial P Q}{\partial y}+g H \frac{\partial \zeta}{\partial x}+\tau_{x} H-S Q=0 \\
& \frac{\partial P}{\partial t}+\frac{\partial P Q}{\partial x}+\frac{\partial Q^{2}}{\partial y}+g H \frac{\partial \zeta}{\partial y}+\tau_{y} H-\rho P=0
\end{aligned}
$$


where $\zeta$ is the free surface elevation above mean sea level; $x$ and $y$ represent the longitude and latitude of the earth; $\tau_{x}$ and $\tau_{y}$ are the bottom shear stress in $x$ axis (pointing to the east) and $y$ axis pointing to the north; $P$ and $Q$ stand for the volume fluxes $(P=H u$ and $Q=H v$ with $u$ and $v$ being the depth-averaged velocities in the longitude and latitude direction); $H$ is the total water depth $(H=h+\zeta)$ with $h$ being the water depth; $f$ represents the Coriolis parameter; and $g$ is the acceleration due to gravity.

The simulation domain covers basically the Alboran Basin, in the western Mediterranean region. The grid is composed of $1095 \times 673$ nodes in $x$ and $y$ axis respectively (cell size of $500 \times 500 \mathrm{~m}$ ). The lower left corner of this grid is located at $\left(6^{\circ} \mathrm{W}, 35^{\circ} \mathrm{N}\right)$. For all the numerical simulations a radiation boundary condition has been considered in all the boundaries falling into the water region, while in all those boundaries separating wet and dry domains, a vertical wall condition has been adopted.

The bathymetry used is the GEBCO_08 dataset (GEBCO, 2008), with an original cell size of $30^{\prime \prime}$ (Fig. 7). The histogram of Fig. 7 presents two clear maximums of frequency, near the minimum and maximum depth of the area. The highest peak of the frequency distribution represents the lower sea bottom of the Alboran Basin towards the east $(\approx-2650 \mathrm{~m}$ ). This deep flat area gradually increases its depth towards the west (blue colors). The northern and southern boundaries of this area show a steep slope, as is evidenced by the closeness of the contours on the coasts of Cartagena (Spain) and Oran (Algeria). Towards the west, the sea bottom is much more irregular, with the presence of several important banks and ridges. The main bathymetric feature is the Alboran Ridge, with NE-SW direction and its flanks formed by recent tectonic activity. To the southeast of this ridge there are a number of banks of which the most important is the Western Cabliers Banks and Eastern Cabliers Bank. Northwest of the Alboran Ridge there is a platform with a mean depth of $\approx-900 \mathrm{~m}$ responsible for the local maximum at this depth of the histogram. Developed on this platform there are several banks and mounts such as the Horseshoe Southern Bank, the Djibouti Bank or the Algarrobo Bank (Fig. 7). The other peak on the histogram represents the continental shelf, showing a value of $\approx-90 \mathrm{~m}$ for the Alboran Basin.

\section{Results}

In order to identify the more exposed areas of the Alboran Sea coasts, we have computed tsunami travel times and maximum wave elevations for each considered scenario. The results are presented in maps covering the Alboran Sea. In a number of locations distributed
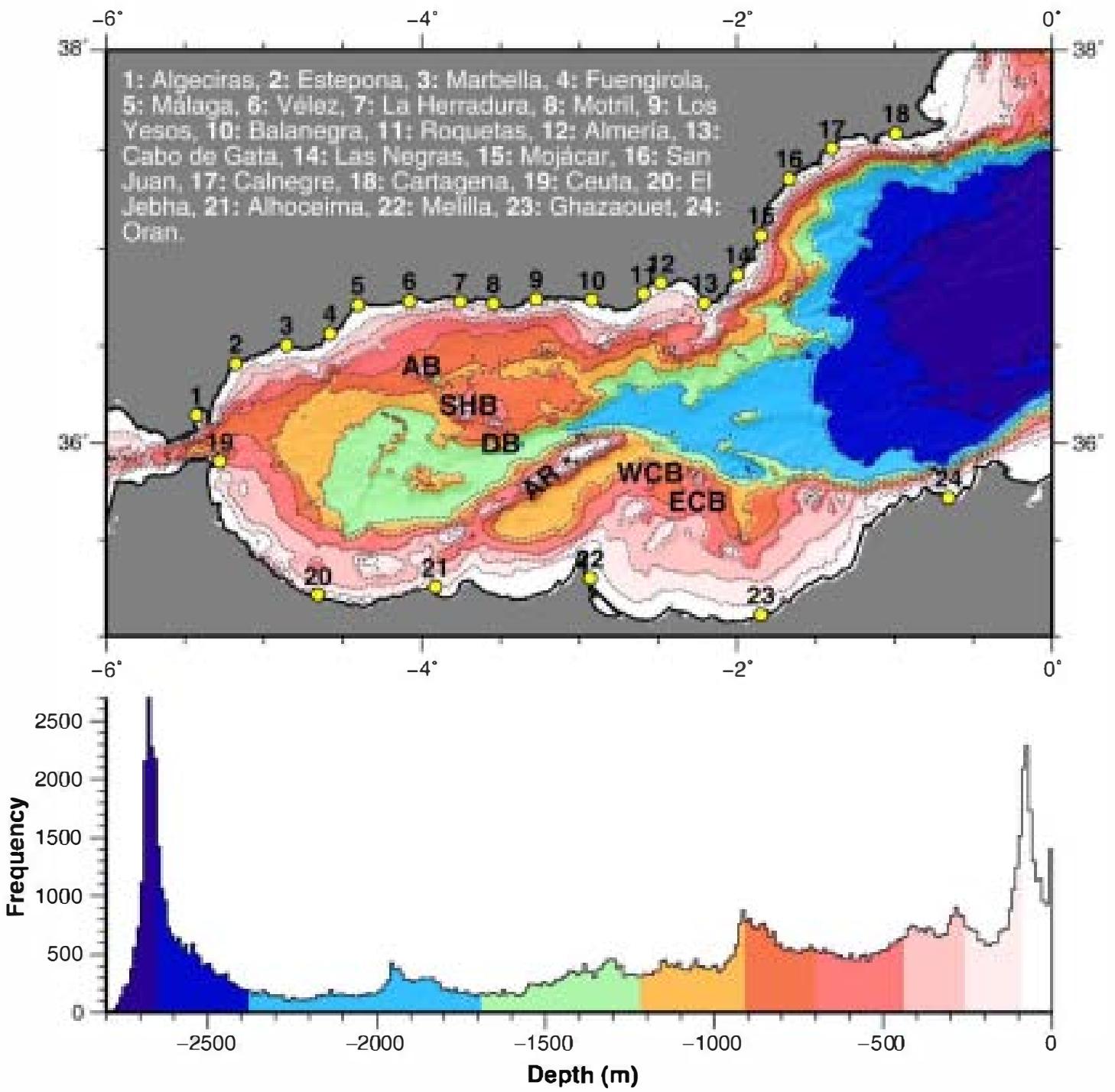

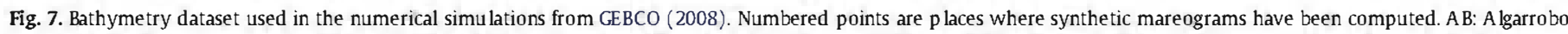

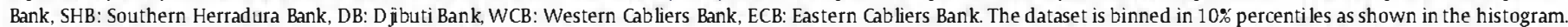


along the coast, synthetic mareograms have been generated to obtain precise estimated tsunami travel times and maximum wave elevations. The data extracted from the synthetic mareograms are shown in the maps too.

In addition to these maps we have performed an approximation to the threat based on a classification of the levels of damage expected as a function of the wave height. We have followed the levels proposed by Tiberti et al. (2008), which follow a three color coded classification similar to the one used by the "Japan Meteorological Agency" (http:// www.jma.go.jp/en/tsunami/). These levels classified the wave elevation in $0.5 \mathrm{~m}$ steps, dividing the threat as "Marine Threat" for maximum wave elevations between $0.05 \mathrm{~m}$ and $0.5 \mathrm{~m}$; "Land Threat" for the range $0.5 \mathrm{~m}$ to $1 \mathrm{~m}$; and "Severe Iand Threat" for maximum wave elevations over $1 \mathrm{~m}$. We have used the $-10 \mathrm{~m}$ contour line from the bathymetry to obtain the expected maximum wave elevation in front of the coast. Using this value we avoid numerical problems and artifacts due to the proximity to the numerical model boundary (the 0 meters contour), while retaining the general characteristics of the wave in each point. Although the model can represent adequately the "general picture" of the hazard, the resolution of the grid is too coarse to study local effects of amplification and resonance, and therefore the obtained results should be considered as lower limits of the expected tsunami impact.

To obtain an estimated tsunami travel time we have used two approximations. On one hand we have computed by means of the COMCOT model synthetic mareograms for a number of locations along the coast (Fig. 7) from which we extracted the tsunami travel time (with a minimum wave elevation threshold of $\approx 0.01 \mathrm{~m}$ ) and the maximum wave elevation travel time (Fig. 8); and on the other hand we have computed tsunami travel times following the technique described by Shokin et al. (1987)and implemented by Luis (2007) to obtain tsunami travel time contours as shown in the maps (Figs. 10 , 12,14 and 17). If we assume that the tsunami wave length is much greater than the water depth, the tsunami travel time can be computed taking into account only the water depth:

$c^{2}=g h$

where $c$ stands for wave propagation speed, $g$ is the acceleration of gravity and $h$ is the water depth. Following the Huygens' Principle the minimum time of travel of a wave front generated on a point can be computed for each node on a grid. The result is independent of the tsunami height or wavelength, which makes this approximation faster and simpler than the numerical modeling of the wave propagation. The main weakness of this technique compared with the more sophisticated numerical models is that in shallow waters the nonlinear effects are not taken into account, and therefore the travel time estimations near the coast have greater errors. Shokin et al. (1987) estimated the error associated with the technique and found

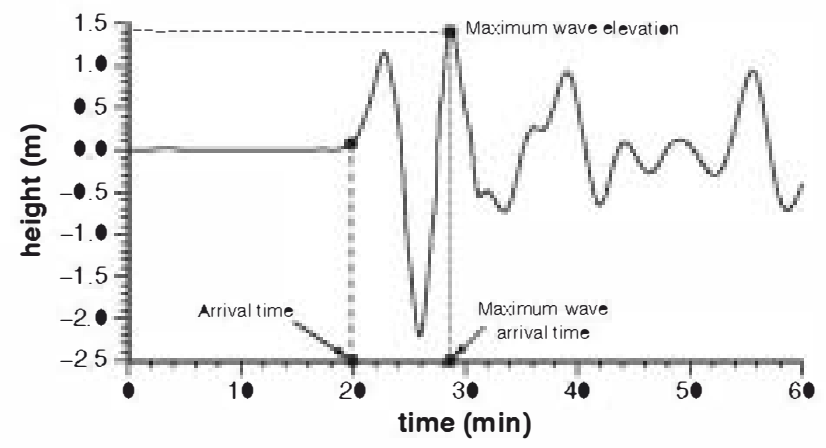

Fig. 8. Synthetic mareogram generated for the ARSFE source in the "La Herradura" location (point 7 of Fig. 7). The points of interest extracted from each mareogram are shown. that usually a $3 \%$ deviation is the maximum error encountered, approximately 2 min per hour.

The maximum elevations have been obtained from the numerical model. We have modeled an hour of wave propagation in 1 minute steps. With this modeling we generated synthetic mareograms for each node of the grid (Fig. 8), from which the maximum wave elevation was extracted. Maps of maximum wave elevation for the Alboran Basin where then generated for each source.

\subsection{Alboran Ridge}

\subsubsection{Alboran Ridge North Fault Eastern (ARNFE)}

As specified above, the sea bottom deformation was computed for each source using the Okada (1985) equations. The maximum vertical displacement of the sea bottom caused by this source is $0.46 \mathrm{~m}$, the maximum horizontal displacement being the same (Fig. 9a). The maximum wave elevation produced in open sea is $\approx 0.72 \mathrm{~m}$, the tsunami being more energetic towards the north-west (Fig. 10a). This propagation towards the Spanish coast causes the maximum elevations in the area of Motril (point 8 in Fig. 7). The African coast presents lower elevations, probably due to the pseudo-barrier that the Alboran Ridge forms to the propagation of the wave, dissipating its energy. The threat in the affected coasts is "Marine", from Marbella (point 3) to Las Negras (point 14) in Spain; and from El Jebha (point 20) to Ghazaouet (point 23) in Africa.

Due to its central position in the Alboran Basin, the tsunami travel time map shows similar travel times for the Spanish and Moroccan coasts, although the presence of the shallows of the Alboran Ridge slows down the propagation of the wave towards the south (Fig. 10a). The first coastline affected by this source is the Cape Tres Forcas, $\approx 15$ min after the rupture, on the Moroccan coast. The first populated area reached by the wave is the Spanish coast between "Castell de Ferro" and "El Pozuelo" (Los Yesos in Fig. 7, point 9), where the continental shelf is very steep. Here the first wave arrival is basically the maximum wave elevation, $17 \mathrm{~min}$ and $18 \mathrm{~min}$ respectively. The coast between Malaga and Murcia (points 5 to 16 in Fig. 7) is exposed to the wave in less than $30 \mathrm{~min}$; as well as the north African coast between Alhoceima (point 21) and Ghazaouet (point 23).

\subsubsection{Alboran Ridge North Fault Western (ARNFW)}

Due to the mainly strike-slip component of this source, the maximum vertical displacement is $0.17 \mathrm{~m}$, while the horizontal left lateral displacement reaches $0.59 \mathrm{~m}$ in the NNE direction of motion (Fig. 9b). Due to its small vertical deformation, the maximum wave elevation obtained is $\approx 0.22 \mathrm{~m}$. This maximum elevation takes place in the epicentral area, in the Alboran Ridge, the elevation along the coasts being lower (Fig. 10b). Similarly to the previous source, the most exposed area is the Spanish coast between Fuengirola (point 4) and Motril (point 8), although only with "Marine" threat. On the Moroccan coast this level of threat is reached locally between El-Jebha (point 20) and Ghazaouet (point 23) although with very low elevations.

The proximity of this source to the Moroccan coast makes the wave arrive in just $14 \mathrm{~min}$ to Alhoceima (Fig. 7, point 21); sweeping the Mediterranean Moroccan coast in less than $30 \mathrm{~min}$ (Fig. 10b). The Cape Tres Forcas forms a barrier protecting the Algerian coast from the incidence of these southern sources. The waves generated take around $45 \mathrm{~min}$ to reach this Algerian coast. On the other hand, the southern Spanish coast is very exposed, and similarly to that which occurs on the Moroccan coast, in $\approx 30 \mathrm{~min}$ all the coasts between Algeciras (point 1) and Mojacar (point 15) are affected.

\subsubsection{Alboran Ridge South Fault Eastern (ARSFE)}

Its dimensions make this source one of the most capable to generate tsunamis in the area; with a maximum vertical displacement of $0.93 \mathrm{~m}$ and maximum horizontal displacement of $0.65 \mathrm{~m}$ (Fig. 9c). 


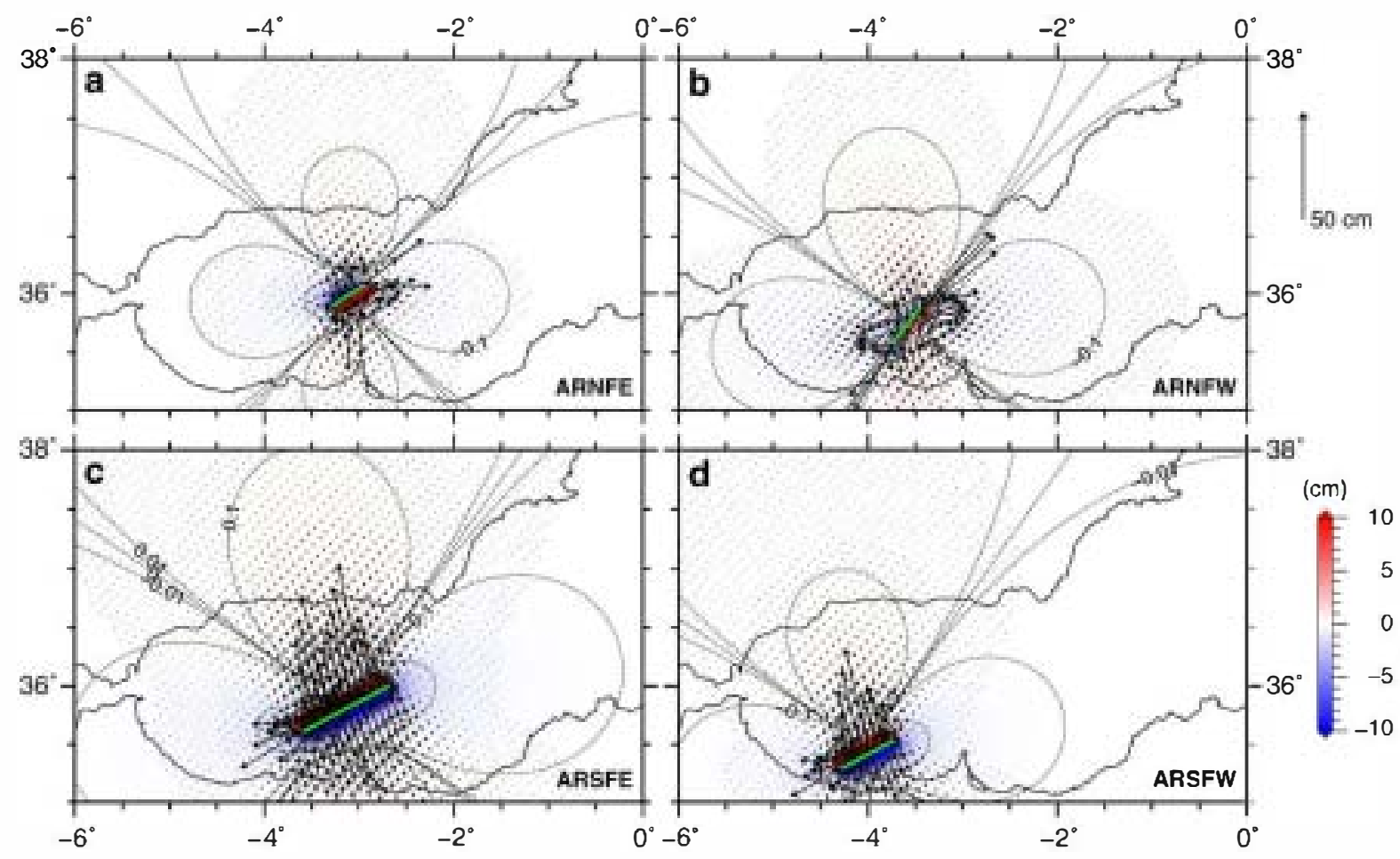

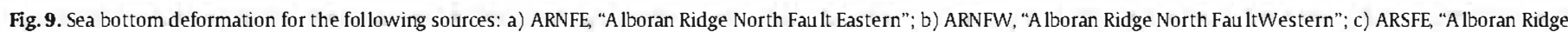
South Fault Eastern"; d) ARSFW, "Alboran Ridge South Fault Western". Colors and contours show vertical disp lacement while the vectors show horizontal disp lacement.

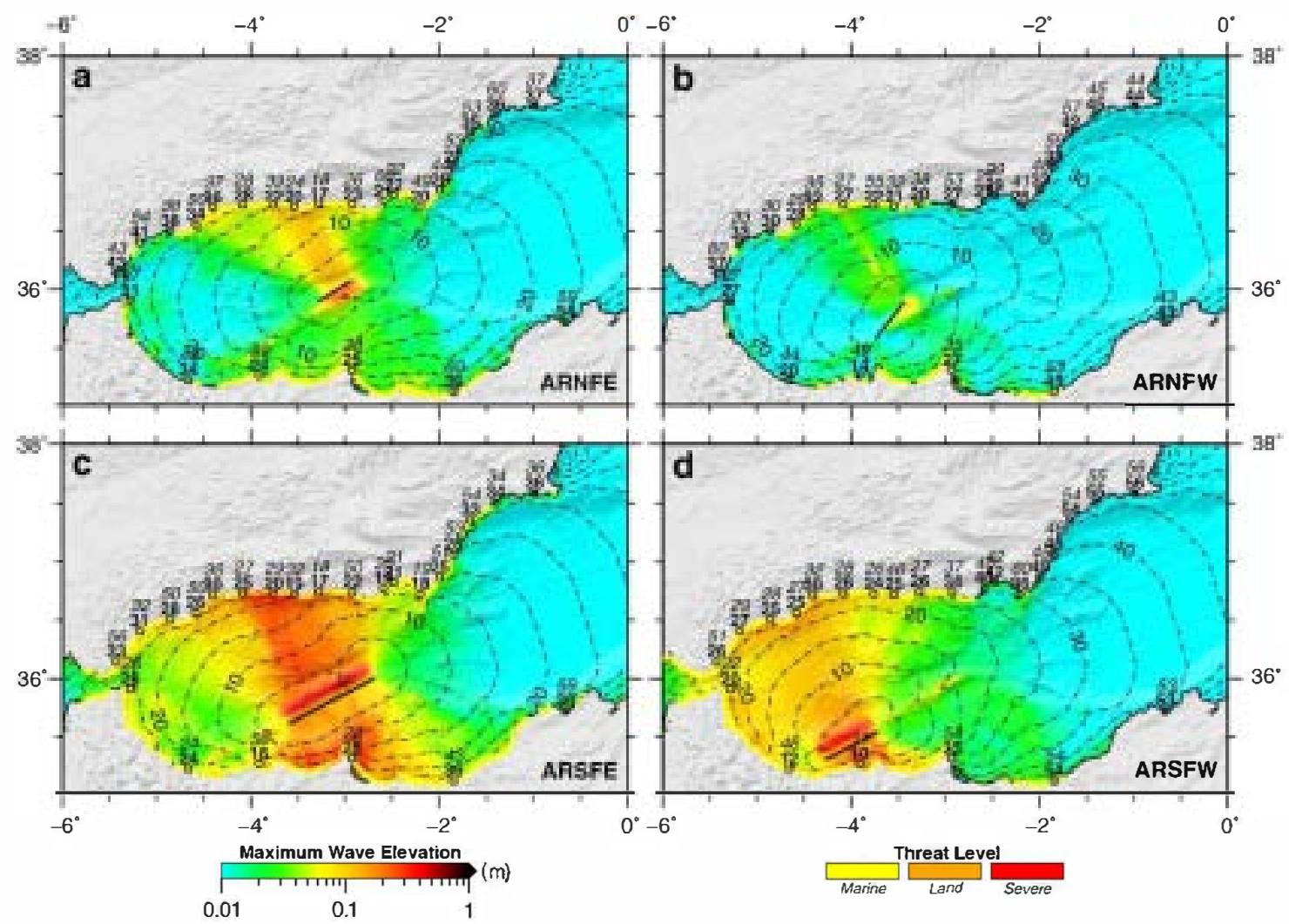

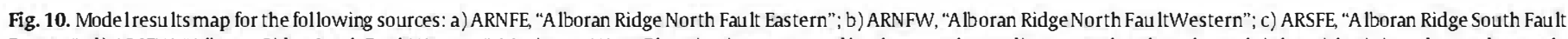

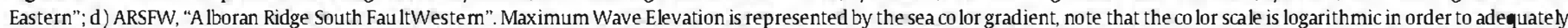

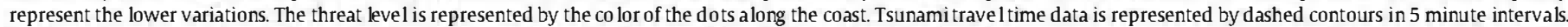

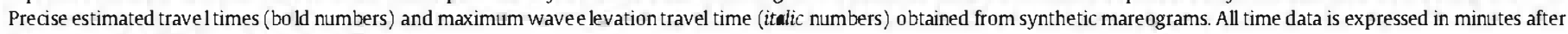
the rup ture. The thick line shows the fault trace. 
The maximum wave elevation generated by this source is the biggest of all the models, reaching values of $1.6 \mathrm{~m}$ along the Alboran Ridge, and greater than $1 \mathrm{~m}$ for some points of the Spanish coast. Almost all the Alboran Basin margins are affected, at least with "Marine" threat level (Fig. 10c); the threat being of "Iand" level locally in the Spanish coast between Fuengirola (point 4) and Balanegra (point 10) and in the western edge of the Cape Tres Forcas in the Moroccan Coast, near Melilla (point 22). The "Severe Land" threat is reached between Velez (point 6) and La Herradura (point 7); although locally this level could also be reached in other areas if we expect amplifications near the coast that are not well represented with our model resolution.

In a similar way to the previous source, the Moroccan and southern Spanish coasts are reached in less than $30 \mathrm{~min}$, the nearest coast being the area between Cape Tres Forcas and Alhoceima, with estimated travel times of $\approx 15 \mathrm{~min}$ (Fig. 10c). Due to the deeper area to the north of the Alboran Ridge, the propagation towards the Spanish coast is faster; and although the distance is greater, the estimated time of travel is lower than 20 min for the coast between Motril and Cabo de Gata (Fig. 3, points 8 and 13 respectively).

\subsubsection{Alboran Ridge South Fault Western (ARSFW)}

This source presents an oblique slip with important reverse component. This produces a maximum vertical displacement of $0.73 \mathrm{~m}$, greater than the maximum horizontal displacement of $0.51 \mathrm{~m}$ (Fig. 9d), generating a maximum wave elevation of $\approx 1.17 \mathrm{~m}$ and elevations greater than $0.5 \mathrm{~m}$ along the Moroccan coast in the area of Alhoceima (point 21) (Fig. 10d). The threat level posed by this source is "Marine" and mainly confined to the western Alboran Basin, being locally of "Land" level in Alhoceima (point 21).

The ARSFW is the southern segment of the Alboran Ridge Fault system and could be continued onshore by the Jebha Fault (Morel and Meghraoui, 1996; Álvarez-Marrón, 1999). The closeness of this source to the Moroccan coast produces travel times of less than 10 min (Fig. 10c) with the maximum wave elevation reaching Alhoceima in 10-11 min (point 21). The Cape Tres Forcas forms an effective barrier for the propagation of the waves towards the east; delaying the travel time of the wave to $54 \mathrm{~min}$ at Ghazaouet. The Spanish coast from Algeciras (point 1) to Balanegra (point 10) is reached in less than $30 \mathrm{~min}$.

\subsubsection{Tofiño Bank Fault (TBF)}

The Tofiño Bank Fault can be interpreted as a reverse splay fault of the Alboran Ridge northern flank. This fault uplifts the Tofiño Bank, situated towards the south, thrusting the northern African margin over the Alboran Basin. The maximum vertical displacement generated by this source is $0.82 \mathrm{~m}$, while the horizontal displacement is $0.47 \mathrm{~m}$ (Fig. 11a).

The waves generated by this source produce the maximum wave elevations along the Moroccan coast in Alhoceima (point 21) and along the Spanish coast in the area of Malaga and Velez (points 5 and 6) (Fig. 12a). Here the threat reaches the "Land" level, and even the "Severe Land" level near Alhoceima.

Similarly to that which takes place in the previous cases, this source is very close to the Moroccan coast, causing very short travel times for the area of Alhoceima (Fig. 12a), less than $10 \mathrm{~min}$. The general features of the tsunami travel time map and the estimated ravel times are almost identical to those of the previous source, with estimated travel times of less than 30 min for the southem Spanish coast, and more than $50 \mathrm{~min}$ for the eastern Moroccan and Algerian coasts.

\subsection{Carboneras Fault}

\subsubsection{Carboneras Fault Southern (CFS)}

This is the segment of the Carboneras Fault situated at greater depths, in front of the Campo de Dalias area, between Balanegra and Roquetas (Fig. 7, points 10 and 11 respectively). This fault is mainly strike-slip in character, although with some dip-slip component that uplifts the northern block. The maximum vertical displacement obtained from the elastic model is $0.16 \mathrm{~m}$, much lower than the maximum horizontal displacement of $0.5 \mathrm{~m}$ (Fig. 11b). The maximum wave elevation is achieved along the fault trace, $\approx 0.27 \mathrm{~m}$, while at the

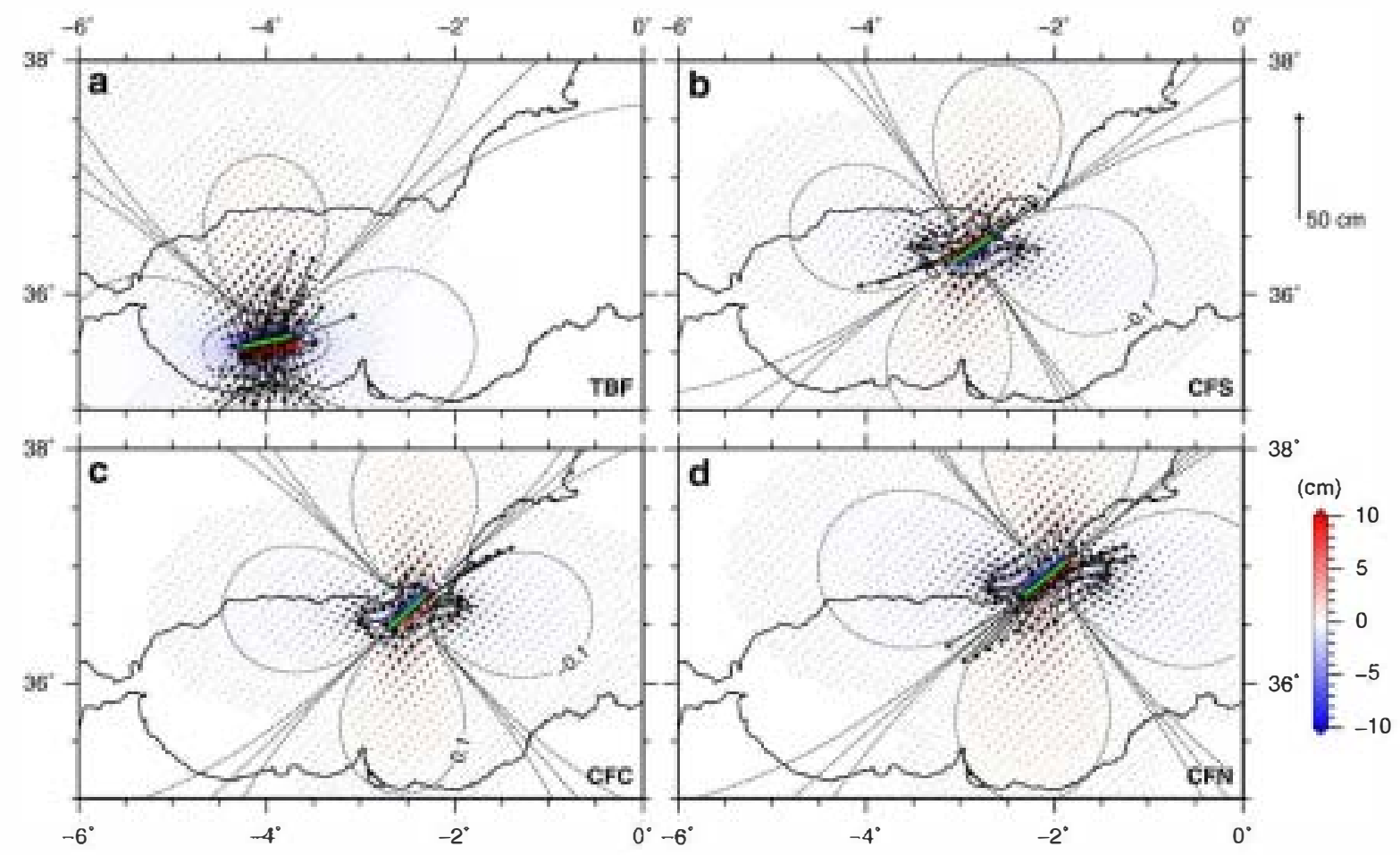

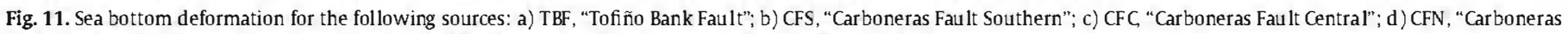
Fault Northern". Colors and contours show vertical disp lacement while the vectors show horizontal disp lacement. 


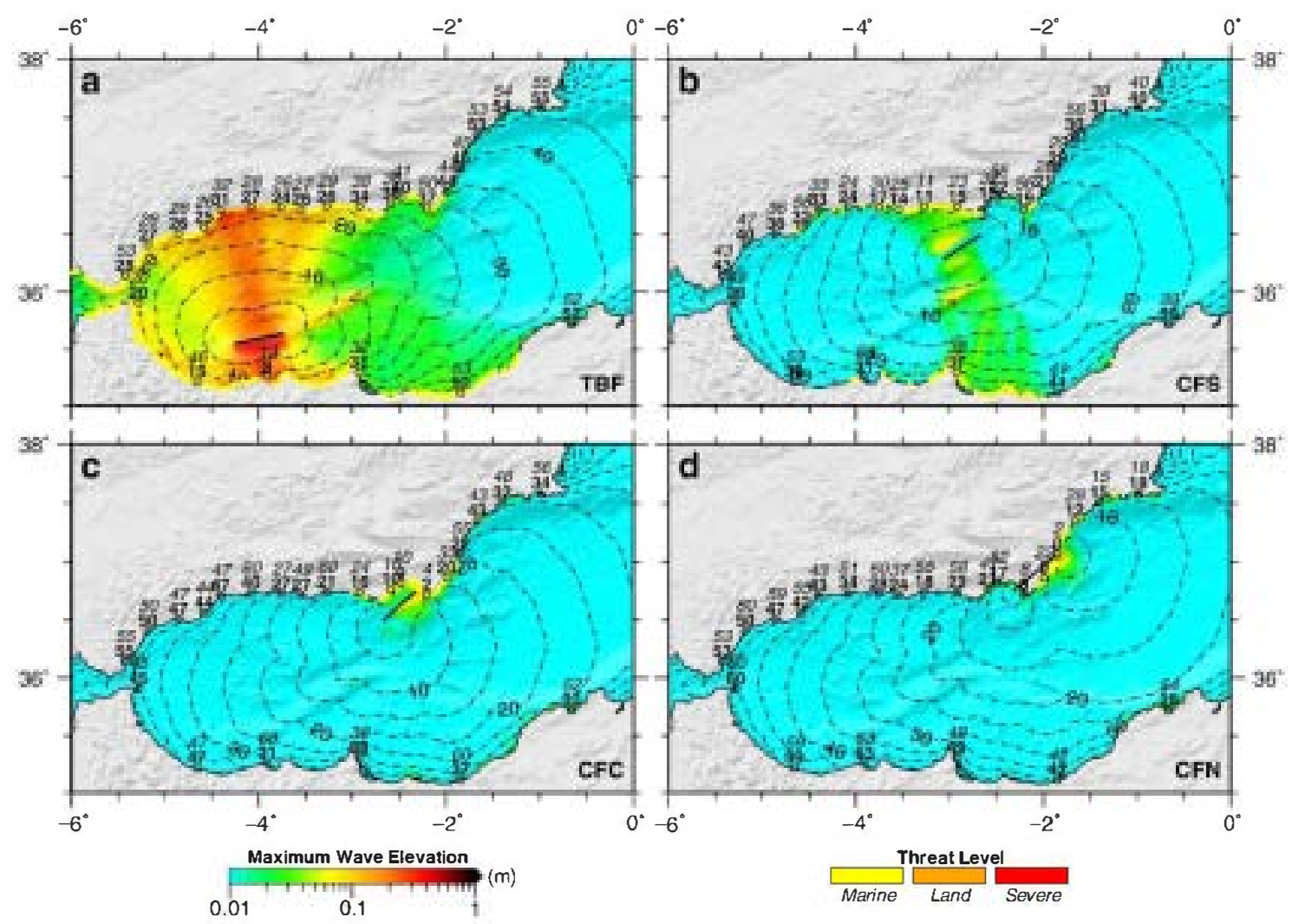

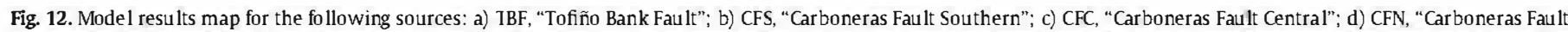

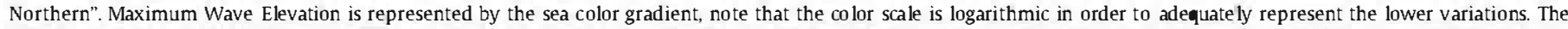

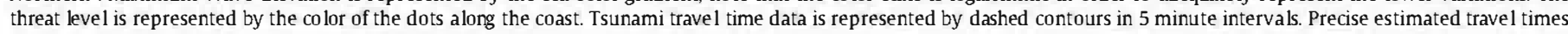

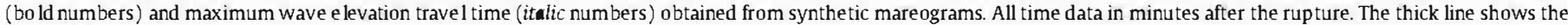
fault trace.

coast the maximum wave elevations are below the $0.1 \mathrm{~m}$. These low elevations generate "Marine" level threat in the Spanish coast between Motril (point 8) and Roquetas (point 11) basically, and in the Moroccan coast between the Cape Tres Forcas, Melilla (point 22) and Ghazaouet (point 23).

The travel times estimated are less than 20 min for a wide Spanish coastal area between La Herradura (Fig. 7, point 7) and Cabo de Gata (point 13) (Fig. 12b). The minimum travel time, $11 \mathrm{~min}$, is located in Los Yesos (point 9), where it coincides with the maximum wave elevation arrival. The travel times for the African margin are more or less homogeneous with times that range from 31 min (Alhoceima, point 21) to $41 \mathrm{~min}$ (Ghazaouet, point 23).

\subsubsection{Carboneras Fault Central (CFC)}

The CFC is the northern segment of the offshore Carboneras Fault. Like the southern segment (CFS) the character of the source is mainly strike slip, with a dip-slip component uplifting the southern block in this case (Fig. 11c). As the dimensions and geometrical characteristics of the CFS and CFC are almost the same (Table 1), the displacements obtained from the elastic numerical model are basically equal. The maximum vertical displacement is $0.16 \mathrm{~m}$ and the horizontal one is $0.52 \mathrm{~m}$. Following the similarities the maximum wave elevation is $\approx 0.24 \mathrm{~m}$, generating small wave elevations along the nearest coast of southern Spain, between Roquetas (point 11) and Las Negras (point 14), the area of Cabo de Gata. This area presents "Marine" threat level.

The main difference between the CFS and CFC is the proximity to the coast of the second one. This proximity makes the propagation of the wave slower in the northern tip of the source, generating a very asymetric wave front (Fig. 12c). On the Spanish coast, the wave is propagated with a coast parallel motion, with increasing travel time values from the Almeria Bay (Fig. 7, point 12). The African coast is reached between Alhoceima (point 21) and Oran (point 24) in less than $40 \mathrm{~min}$, the furthest locations, in the Gibraltar Strait, being reached in $45-55 \mathrm{~min}$.

\subsubsection{Carboneras Fault Northern (CFN)}

The CFN is the onshore segment of the Carboneras Fault, and although its main rupture is not situated under the sea, its proximity could generate some deformation in the adjacent coastal areas (Fig. 11d). The dimensions and geometrical characteristics of this source are very similar to those of the other segments of the Carboneras fault (Table 1). The maximum vertical displacement is $0.17 \mathrm{~m}$ and the maximum horizontal displacement is $0.48 \mathrm{~m}$. The maximum wave elevation generated is very similar to the previous sources, a maximum value of $\approx 0.25 \mathrm{~m}$ along the fault trace (Fig. $12 \mathrm{~d}$ ). In this case, the trace being almost entirely situated onshore, the coastal area affected by the wave is restricted to the northern edge of the fault. A "Marine" threat level, with very low wave elevations is expected between Las Negras (point 14) and Mojacar (point 15).

Since it is an onshore rupture which is close to the coast, the sea disturbation in the nearest coastal points is almost instantaneous (Fig. 12d). The locations of Las Negras and Mojacar (points 14 and 15 in Fig. 7) show estimated ravel imes of 0 min. The area between Almeria (point 12) and Cartagena (point 18) is reached in less than $20 \mathrm{~min}$. The time needed by the wave to arrive at the Spanish coast westward of Malaga (point 5) and at the Moroccan coast is greater than $40 \mathrm{~min}$. In the African coast the nearest location to the source is the Oran area (point 24), where the wave arrives $28 \mathrm{~min}$ after the rupture.

\subsubsection{Carboneras Fault Central and Northern (CFC + CFN)}

The northern and central segments of the Carboneras Fault form a continuous trace with identical strike. Probably both segments 


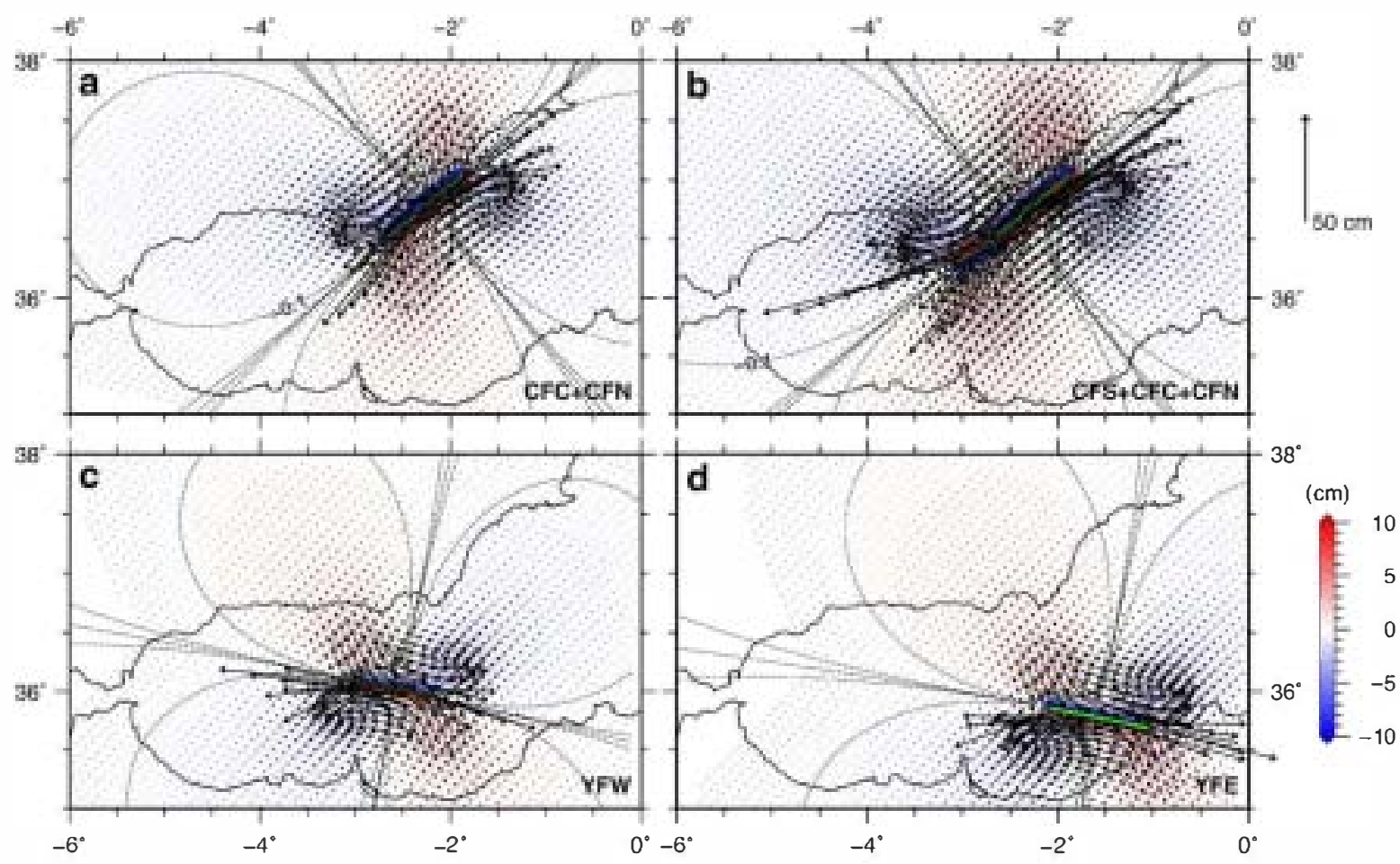

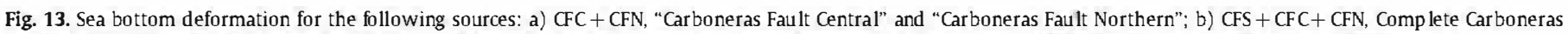
Fault; c) YFW, "Yusuf Fault Western"; d) YFE, "Yusuf Fault Eastern". Colors and contours show vertical disp lacement whi le the vectors show horizontal disp lacement.

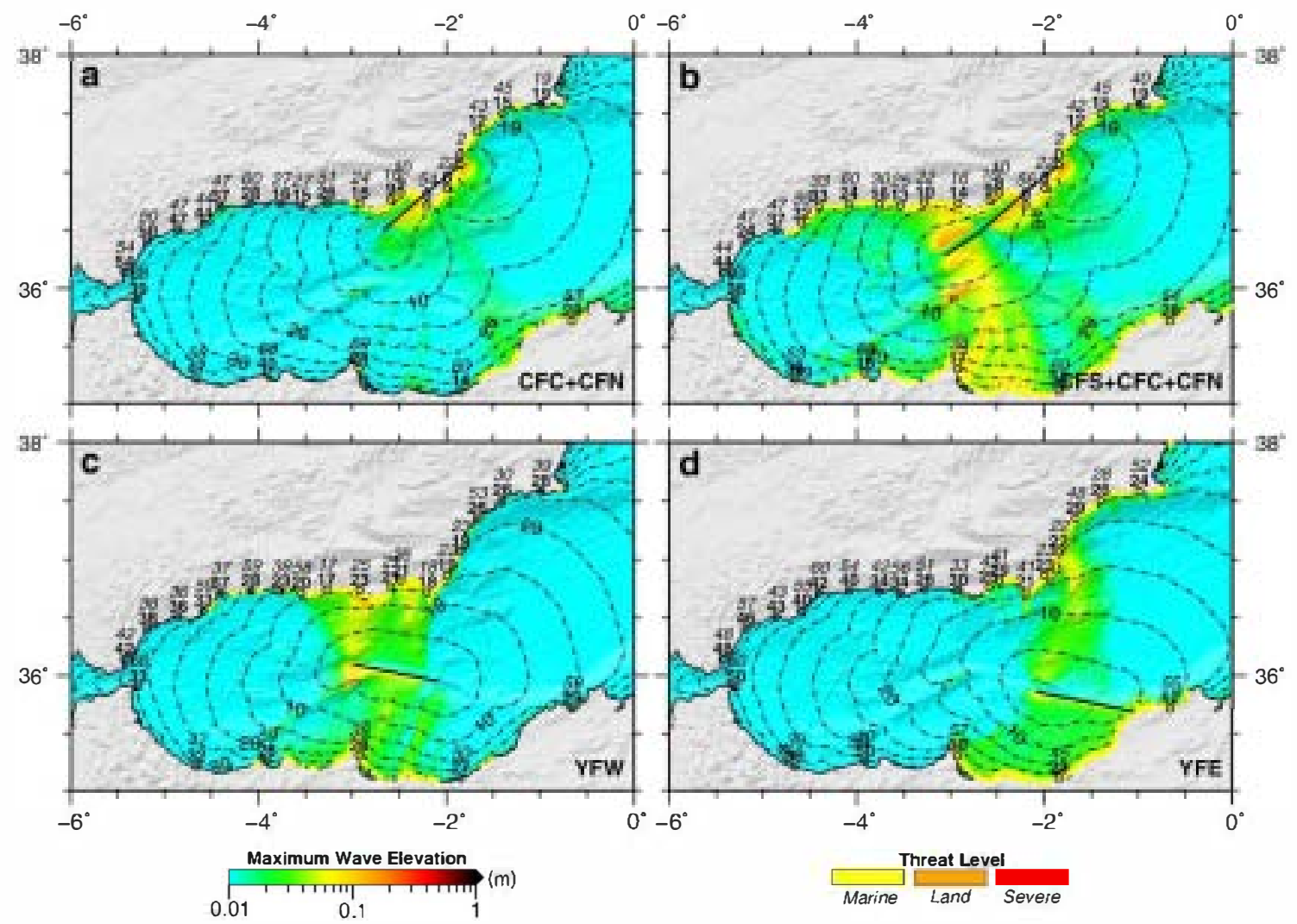

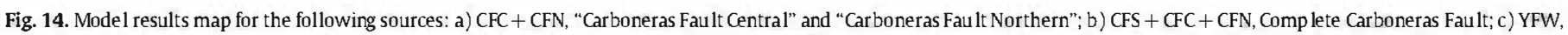

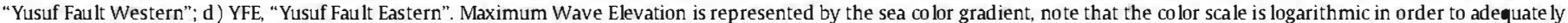

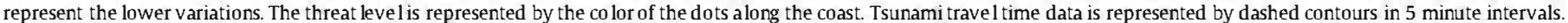

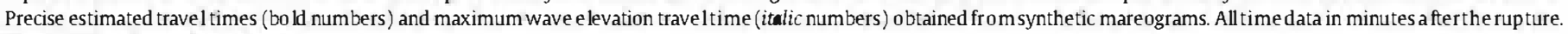
The thick line shows the fault trace. 
present similar dip and rupture characteristics (Gràcia et al., 2006) and hence a continuous rupture of both segments in one shock cannot be ruled out. The size of the earthquake generated by this rupture is $\mathrm{M}_{\mathrm{W}} \approx 7.1$, producing a maximum vertical displacement of $0.24 \mathrm{~m}$ and a maximum horizontal displacement of $0.82 \mathrm{~m}$ (Fig. 13a). In this case the maximum wave elevation generated is $\approx 0.43 \mathrm{~m}$, almost twice the elevation generated by the CFC or the CFN alone (Fig. 14a). Although the tsunami promoted by the combination of both segments is greater than the previous tsunamis of the Carboneras Fault, its size is still small, and only a "Marine" threat level is reached between Balanegra (point 10) and Calnegre (point 17) on the Spanish coast, and between Ghazaouet (point 23) and Oran (point 24) in northern Africa.

The tsunami travel time map and data is obviously a combination of those two segments, the CFC and CFN (Fig. 14a). Great part of the Spanish coast, from La Herradura (point 7) to Cartagena (point 18), is reached by the wave in less than $20 \mathrm{~min}$; while the Algerian coast is affected in less than 30 min.

\subsubsection{Carboneras Fault Complete (CFS $+\mathrm{CFC}+\mathrm{CFN}$ )}

Extending the reasoning of the previous source, we can expect, although to alesser degree, a rupture of the whole Carboneras Fault. This rupture could have a length of $138 \mathrm{~km}$, generating a $\mathrm{M}_{\mathrm{W}} 7.24$ earthquake (Table 1). The maximum vertical and horizontal deformations obtained from the elastic modeling are $0.29 \mathrm{~m}$ and $0.98 \mathrm{~m}$ respectively (Fig. 13b). The maximum wave elevation is $\approx 0.54 \mathrm{~m}$, greater than the previous source with a two segment rupture, but capable only of generating wave elevations of a few decimeters along the coast. The area affected is increased greatly, presenting "Marine" threat levels from Fuengirola (point 4) to Cartagena (point 18) in Spain, and from Alhoceima (point 21) to Oran (point 24) in Africa (Fig. 14b).

The addition of this southern segment to the rupture diminishes the tsunami travel time towards the west (Fig. 14b). In the eastern part of the Alboran Basin the tsunami travel time is almost identical to the previous source, while towards the west the main part of the coast is reached by the waves in less than $30 \mathrm{~min}$.

\subsection{Yusuf Fault}

\subsubsection{Yusuf Fault Western}

The YFW is an almost pure right lateral strike-slip structure; and although its rupture dimensions can generate an earthquake of magnitude $\approx \mathrm{M}_{\mathrm{W}} 7$, the vertical deformation is small compared to the horizontal one. The maximum vertical sea bottom displacement obtained is $0.20 \mathrm{~m}$, while the maximum horizontal displacement is 0.76 (Fig. 13c). Consequently, the maximum wave elevation is small, $\approx 0.30 \mathrm{~m}$, a value similar to those obtained from the other almost pure strike-slip fault, the Carboneras Fault. On the coast, the greatest values are obtained along the Cape Tres Forcas coast in Morocco (point 22), and the Campo de Dalias coast in Spain (point 10); although they only pose a "Marine" threat level (Fig. 14c).

The YFW is practically centered on the Alboran Basin, giving rise to similar travel times along the Spanish and African coasts (Fig. 14c). The lower travel times are situated in southeastern Spain, in the area between Cabo de Gata and Mojacar (Fig. 7, points 13 to 15), where the estimated travel times are below $20 \mathrm{~min}$. In the Los Yesos location (point 9) the time is also small, probably due to the steep continental shelf, making the waves travel faster than in the rest of continental margin. The greatest travel times are located in the Gibraltar strait, with a minimum travel time of $42 \mathrm{~min}$ in Algeciras (point 1).

\subsubsection{Yusuf Fault Eastern}

The characteristics of this source are very similar to the previous one, although the dimensions are greater, hence causing a larger magnitude earthquake ( $\mathrm{M}_{w}$ 7.03). The maximum vertical displacement is similar to that of the previous case, $0.18 \mathrm{~m}$, with a maximum horizontal displacement of $0.80 \mathrm{~m}$ (Fig. 13d). The maximum value of wave elevation is a little higher, $\approx 0.37 \mathrm{~m}$, and the affected coast is basically the eastern Alboran Basin margin, with a "Marine" threat level (Fig. 14d). The maximum values along the coast are reached in the area of Ias Negras (point 14) and Mojacar (point 15), in Spain.

The eastern edge of this fault is located near the Algerian coast, and consequently the estimated travel times for the Oran area are the lowest (Fig. 14d); 12 min for the Oran location (point 24 in Fig. 7). Basically the entire coast of the eastern area of the Alboran Basin is reached by the waves in less than $30 \mathrm{~min}$. It is remarkable that, although the distance to the Spanish coast from the source is greater than the distance to the rest of Algerian and eastern Moroccan coast, the times are very similar and even lower on the Spanish side. This difference is due to the deeper northern part of the Alboran Basin, and is clearly seen in Fig. 7.

\section{Discussion}

It is important to keep in mind that the results can be considered as an average of the expected tsunami impact due to the following reasons: (1) the detail of the base of the numerical model; the bathimetry and topography data and cell size, are not enough to take into account the non-linear effects of resonance and amplification in the near shore area. (2) The modeled ruptures are considered to be homogeneous slips over the fault area, while in fact the ruptures are not homogeneous, with the possible presence of deformation peaks in the "real world" resulting locally in greater maximum sea bottom deformations. Therefore our results adequately show the estimated travel times and the more exposed areas, but the maximum elevations and expected damage could locally be higher.

In this work a deterministic analysis has been carried out. This considers the worst case scenarios of those faults affecting the study area; as a result the maximum tsunami elevation along the coast associated to each potential source is obtained (Figs. 10, 12 and 14). In addition to these worst case scenarios for each fault, the worst effects produced by the joint contribution of these scenarios had been computed (Fig. 17). The fact is that a given worst case scenario can create great damage in a certain area and yet not have any effect in another region. But maybe there is another worst case scenario that created the opposite effect. When computing the joint contribution of all the worst case scenarios, all regions will show the maximum effect that all the considered fault worst case scenarios can create in that region. González et al. (2010) applied an indirect statistical method to estimate the tsunami hazard along the Alborán Sea Coast. This probabilistic approximation uses the Monte Carlo Technique to combine the probability of occurrence of earthquakes in five potential sources, source mechanisms and epicenter locations. The results are maximum tsunami elevation associated to return period in years along the coast. A more exhaustive source characterization has been carried out in the present work allowing the inclusion of new potential sources such as the Carboneras fault and the Yusuf fault, which have not been included in González et al. (2010). However, results in both works are consistent, with important tsunami wave elevation in areas such as Málaga and Melilla. The maximal wave elevation close to $1.5 \mathrm{~m}$ obtained in the present work could be associated to $1000-1500$ year return period (99.99\% confidence level) obtained by González et al. (2010).

Deterministic and probabilistic hazard maps are complementary tools. Deterministic maps could be useful, for example for the establishment of the maximum wave elevation limits along the coast and the identification of the zones most exposed to tsunami events. On the other hand, the probabilistic maps are more valuable for Vulnerability and Risk assessment and also for insurance proposes, because they provide a more realistic idea of the hazard of a given zone.

From the observation of the contribution of each source to the maximum wave elevation expected along the Spanish (Fig. 15) and African (Fig. 16) coasts, we can conclude that the ARSFE, ARSFW and 

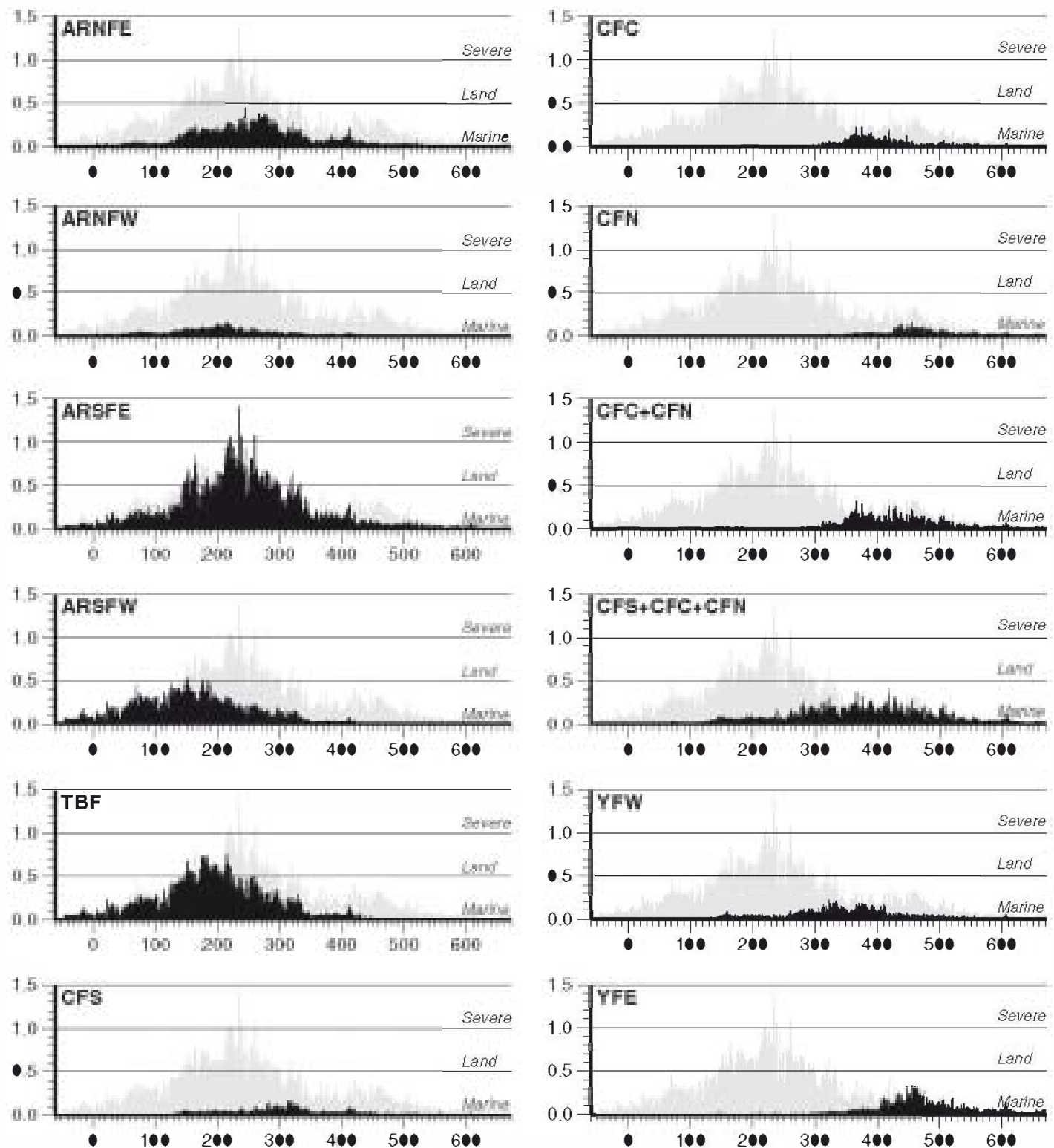

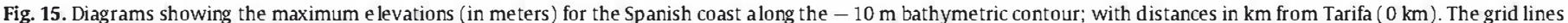
show the different levels of threat. The maximum wave elevation aggregated from all the sources is shown in gray.

TBF sources are more dangerous ones. These three sources generate the highest elevations along the coast (Table 2), especially in the western Alboran Basin.

On the Spanish coast, the area comprised between Fuengirola (point 4) and Roquetas (point 11) (Fig. 17) is the most threatening, with the greatest elevations between Malaga (point 5) and La Herradura (point 7). In this area the "Land" threat level is common, as well as the "Severe Land" threat level. These threat levels are only generated by the sources associated with the Alboran Ridge, the aforementioned ARSFE, ARSFW and TBF (Table 2). The eastern segment of the Spanish coast is mainly affected by the sources of the eastern Alboran Basin, mainly by the combination of the segments of the Carboneras Fault ( $\mathrm{CFS}+\mathrm{CFC}+\mathrm{CFN}$ ), but also by the eastern segment of the Yusuf Fault (YFE) (Fig. 15). Nevertheless the threat level achieved in this eastern area is only of "Marine" type and disastrous tsunamis seem very improbable, although our results are very conservative and other local variables as resonance, fault slip peaks, or even submarine landslides could promote the formation of unexpected greater waves.
Along the African coast, in general, the threat level and maximum wave elevations are lower than in the Spanish coast (Figs. 16 and 15). Only the three sources mentioned above (ARSFE, ARSFW and TBF) are capable of generating enough energy to seriously threaten the African margin of the Alboran Basin. The area more exposed to the effects of a tsunami in this coast is that which is comprised between Alhoceima (point 21) and Melilla (point 22) (Fig. 17) due to its position in front of the structures associated with the Alboran Ridge. The African coast of the eastern Alboran Basin is "protected" by the presence of the isthmus of the Cape Tres Forcas. This rocky peninsula forms a natural barrier against the propagation of the wave train towards the east from the sources of the western Alboran Basin. This difference is also evident in the level of threat, reaching the "Land" threat in the western area (even "Severe" near Alhoceima) but only "Marine" in the eastern. The sources of the eastern Alboran Basin studied in this work seem unlikely sources of disastrous tsunamis, showing maximum wave elevations of a few decimeters (Table 2 and Fig. 17).

The sources described in this work can be grouped into three main tectonic structures or deformation corridors: the Alboran Ridge, the 

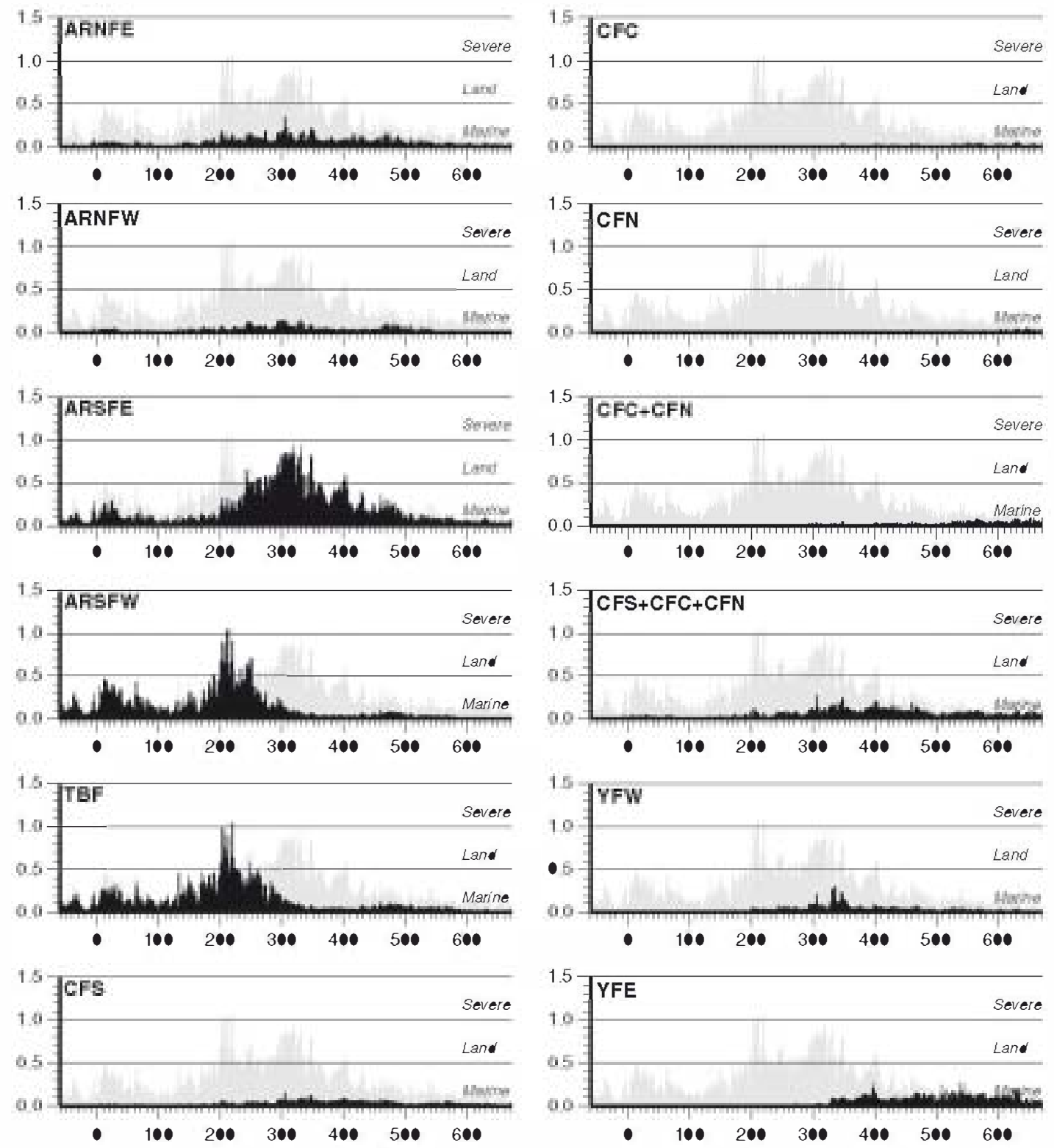

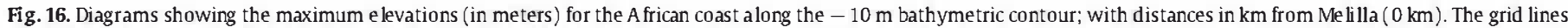
show the different levels of threat. In gray is shown the maximum wave elevation aggregated from all the sources.

Table 2

Compilation of main propagation results. MVD: Maximum vertical disp lacement of the sea bottom; MWE: Maximum wave elevation; MAT: Minimum travel time; MTL: Maximum threat level. ARNFE: Alboran Ridge North Fault Eastern; ARNFW: Alboran Ridge North Fault Western; ARSFE: Alboran Ridge South Fault Eastern; ARSFW: Alboran Ridge South Fault Western; TBF: Tofiño Bank Fault; CFS: Carboneras Fault Southern; CFC: Carboneras Fault Central; CFN: Carboneras Fault Northern; YFW: Yusuf Fault Western; YFE: Yusuf Fault Eastern.

\begin{tabular}{lllll}
\hline Fault & MVD $(\mathrm{m})$ & MWE $(\mathrm{m})$ & MAT $(\mathrm{min})$ & MTL \\
\hline ARNFE & 0.46 & 0.72 & 15 & Marine \\
ARNFW & 0.17 & 0.22 & 14 & Marine \\
ARSFE & 0.93 & 1.6 & 10 & Severe \\
ARSFW & 0.73 & 1.17 & 9 & Land \\
TBF & 0.32 & 1.15 & 8 & Severe \\
CFS & 0.16 & 0.27 & 11 & Marine \\
CFC & 0.16 & 0.24 & 2 & Marine \\
CFN & 0.17 & 0.25 & 0 & Marine \\
CFC+CFN & 0.24 & 0.43 & 0 & Marine \\
CFS + CFC+CFN & 0.29 & 0.54 & 0 & Marine \\
YFW & 0.20 & 0.30 & 14 & Marine \\
YFE & 0.18 & 0.37 & 12 & Marine \\
\hline
\end{tabular}

Carboneras Fault and the Yusuf Fault Zone. The Alboran Ridge is the only one that seems to be capable of generating tsunamis with enough energy to seriously affect both margins of the Alboran Sea. Its transpressive deformation promotes the formation of structures with important dip-slip component. These structures have the capacity to deform the sea bottom with an important vertical displacement (Table 2 and Figs. 9a,c,d and 11a).

The Carboneras Fault Zone is only capable of generating tsunamis with local damage in the nearest areas, and only for those ruptures involving at least two segments (estimated $\mathrm{M}_{\mathrm{w}} 7$ or greater). The basically strike-slip displacement of these faults promotes very little vertical deformation in proportion to the total displacement (Table 1). The same reasoning can be extended to the Yusuf Fault. Nevertheless the closeness of these sources to the coast can trigger significant landslides on the continental slope, which can promote tsunamis that can be damaging at a local scale. This type of landslide triggered tsunamis should be considered as a potential hazard in the area between Los Yesos (point 9) and San Juan (point 16) on the Spanish coast (Fig. 7) and in the area of Oran (point 24) on the African coast (Fig. 7). 

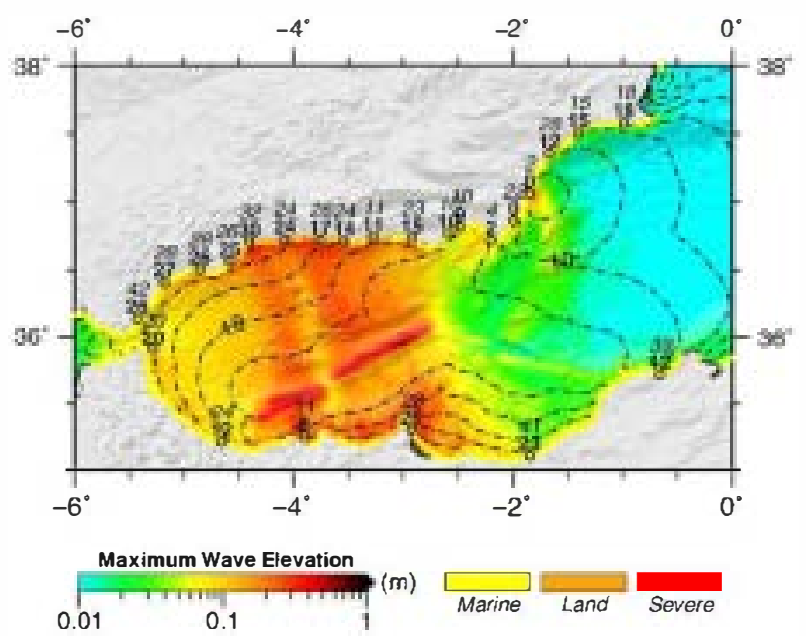

Fig. 17. Map of the aggregation of the considered sources results. The maximum value of the wave elevation from all the considered scenarios has been selected for each cell For the tsunami travel times, the value selected was the minimum from all the scenarios. Maximum Wave Elevation is represented by the sea color gradient. Note that the color scale is logarithmic in order to adequately represent the lower variations. The threat level is represented by the color of the dots along the coast. Tsunami travel time data is represented by dashed contours in 5 minutes intervals. Precise estimated travel times (bold numbers) and maximum wave elevation travel time (italic numbers) were obtained from synthetic mareograms. All time data is in minutes after the rupture.

As can be seen in Fig. 17, the margins of the Alboran Sea can be affected by a tsunami in less than 30 min throughout its entire length, at least with "Marine" threat level. In order to have enough time to react to a tsunami threat, it is basic to have a local tsunami warning system with the capacity to alert and inform the authorities. This is the only way to minimize the possible damages of a tsunami in such a short time, even with just "Marine" threat level.

From this work, we can draw conclusions about the methodology used in tsunami risk studies in the definition of seismic sources. They generally use sources based on specific events, whose characteristics are known. However, in areas where there have been no significant historical events, no such data exist. To remedy this lack of data, generic seismic sources are used. The characteristics of the sources are taken from known events in similar tectonic environments; for example, the Forecast Propagation Database of the NOAA (http://nctr. pmel.noaa.gov/propagation-database.html), that replicates typical subduction events, or the sources proposed for the Mediterranean by Lorito et al. (2008) with typical characteristics based on the tectonic environment. However, in tectonically complex areas such defining generic sources are difficult and risky, given the implications for the planning of local warning systems. If besides being a tectonically complex area, the strain rate is low and typical seismic cycles for major structures can span thousands of years, then the only possible tool for defining these structures is geology, as the instrumental seismicity is not representative of the seismic cycle of major faults. In this paper we have presented a set of sources for the Alboran Sea area based on geological and oceanographic studies. The characteristics of these sources should be reviewed and redefined according to the advance of our knowledge of the geology of the area, which will improve future estimates of tsunami hazard.

\section{Conclusions}

The Alboran Ridge is the only deformation corridor that seems to be capable of generating tsunamis with enough energy to seriously affect both margins of the Alboran Sea.
The Carboneras and Yusuf faults, due to its mainly strike-slip component, are unable to generate damaging tsunamis; although they can trigger locally submarine landslides which can cause local tsunamis.

The margins of the Alboran Sea can be affected by a tsunami with at least "Marine threat" level in less than $30 \mathrm{~min}$. To minimize the possible damages of a tsunami in such a short time it is basic to have a local tsunami warning system and an informed and educated population.

In tectonically complex areas the definition of the tsunamigenic seismic sources should be based on detailed geological and oceanographic studies. The use of generic sources is difficult and risky given the implications for the planning of local warning systems.

The set of sources presented in this work is an advance for the estimations of tsunami hazard in the area, although it should be reviewed, and redefined if necessary, according to the advance of our knowledge of the geology of the Alboran Basin.

\section{Acknowledgments}

This work has been developed in the context of the European project TRANSFER (Tsunami Risk ANd Strategies For the European Region-6.3. IV.2.2-037058; http://abtinti4.df.unibo.it/transfer/). The comments of Juan M. Insua Arévalo, Christian Hüibscher and an anonymous reviewer contributed to the improvement of this work. The figures have been mainly produced with GMT (Wessel and Smith, 1998). This is a contribution from the Ocean \& Coastal Research Group from the Instituto de Hidráulica Ambiental (Universidad de Cantabria) and the Active Tectonics and Paleoseismicity research group (UCM-910368).

\section{References}

Álvarez Gómez, J.A., 2009. Tectónica Activa y Geodinámica en el Norte de Centroam érica. Ph.D. thesis, Universidad Complutense de Madrid, Madrid.

Álvarez-Marr ón, J., 1999. Pliocene to Holocene structure of the eastern Alboran Sea (Western Mediterranean). In: Zahn, R, Comas, M.C, Klaus, A. (Eds.), Proceedings of the ODP, Scienti fic Results, Vol. 161, pp. 345-355.

Ballesteros, M., Rivera, J., Muñoz, A., Muñoz-Mart ín, A., Acosta, J., Carbó, A., Uchupi, E., 2008. A lboran Basin, southern Spain-part 11: neogene tectonic imp lications for the orogenic float model. Marine and Petroleum Geology 25, 75-101.

Bell, J., Amelung, F., King, G., 1997. Preliminary late quaternary slip history of the Carboneras fault, southeastern Spain. Journal of Geodynamics 24 (1-4), 51-66.

Booth-Rea, G., Aza ñón, J.M., Azor, A., García-Due ñas, V., 2004. Influence of strike-slip fault segmentation on drainage evolution and topography. A case study: the Palomares Fault Zone (southeastern Betics, Spain). Journal of Structural Geo logy 26 , $1615-1632$.

Booth-Rea, G., Ranero, C.R., Mart ínez-Mart ínez, J.M., Grevemeyer, I., 2007. Crustal types and Tertiary tectonic evolution of the Alborán sea, western Mediterranean. Geochemist ry Geophysics Geosystems 8 (10), Q10005. doi:10.1029/2007GC001639.

Bourgois, J., Mauffret, A., Ammar, N.A., Demnati, N.A., 1992. Multichannel seismic data imaging of inversion tectonics of the Alboran Ridge (Western Mediterranean Sea). Geo-Marine Letters 12, $117-122$

Buforn, E., Udias, A, Madariaga, R., 1991. Intermediate and deep earthquakes in Spain. Pure and Applied Geophysics 136 (4), 375-393.

Buforn, E., Coca, P., Udias, A., Iasa, C., 1997. Source mechanism of intermediate and deep earthquakes in southern Spain. Journal of Seismology 1(2), 113-130.

Campos, J., Maldonado, A., Campillo, A., 1992. Post-Messinian evolutional patterns of the central A lboran Sea. Geo-Marine Letters 12 (2), 173-178.

Comas, M.C., Soto, J.l, 1999. Brittle deformation in the metamorphic basement at site 976: imp lications for Midd le Miocene extensional tectonics in the western A lboran Basin. In: Zahn, R., Comas, M.C., Klaus, A. (Eds.), Proceedings of the Ocean Drilling Program, Scientific Results, Vol. 161, pp. 331-344

Comas, M.C., García-Due ñas, V., Jurado, M.J., 1992. Neogene tectonic evolution of the A lboran Basin from MCS data. Geo-Marine Letters 12, 157-164.

Díaz, J., Gallart, J., 2009. Crustal structure beneath the Iberian Peninsula and surrounding waters: a new compilation of deep seismic sounding results. Physics of The Earth and Planetary Interiors 173, 181-190.

Doblas, M., Oyarzun, R., 1989. Mantle core complexes and Neogene extensional detachment tectonics in the western Betic Cordilleras, Spain: an alternative model for the emp lacement of the Ronda peridotite. Earth and Planetary Science Letters 93, 76-84.

Docherty, C, Banda, E., 1995. Evidence for the eastward migration of the Alboran Sea based on regional subsidence analysis: a case for basin formation by delamination of the subcrustal lithosphere? Tectonics 14 (4), 804-818. 
Estrada, F., Ercilla, G., Alonso, B., 1997. Pliocene - Quaternary tectonic-sedimentary evolution of the NE Alboran Sea (SW Mediterranean Sea). Tectonophysics 282 423-442.

Faccenna, C, Piromallo, C., Crespo-Blanc, A, Jo livet, L., Rossetti, F., 2004. Iateral slab deformation and the origin of the western Mediterranean arcs. Tectonics 23, TC1012. doi: 10.1029/2002TC001488.

Fernández-Ibáñez, F., Soto, J.I, 2008. Crustal rheology and seismicity in the Gibraltar Arc (western Mediterranean). Tectonics 27. doi:10.1029/2007TC002192.

Fernández-Ibáñez, F., Soto, J.L, Zoback, M.D., Morales, J., 2007. Present -day stress fie ld in the Gibraltar Arc (western Mediterranean). Journal of Geophysical Research 112 , B08404. doi: 10.1029/2006JB004683.

Fullea, J., Fernández, M., Zeyen, H., Verg és, J., 2007. A rapid method to map the crusta and lithospheric thickness using elevation, geoid anomaly and thermal analysis. Application to the Gibraltar Arc System, Atlas Mountains and adjacent zones. Tectonophysics $430,97-117$

García-Due ñas, V., Balanyá, J.C, Martínez-Martínez, J.M, 1992. Miocene extensional detachments in the outcropping basement of the northern Alboran Basin (Betics) and their tectonic imp lications. Geo-Marine Ietters 12 (2-3), 88-95.

GEBCO, 2008. The GEBCO_08 Grid, version 20081212. http://wwwgebconet.

González, M., Medina, R, Olabarrieta, M., Otero, L., 2010. Tsunami hazard assessment in the Southern coast of Spain. Turkish Journal of Earth Sciences 19, 351-366.

Gr àcia, E., Pallàs, R., Soto, J.I., Comas, M., Moreno, X., Masana, E., Santanach, P., Diez, E. García, M., Dañobeitia, J., 2006. Active faulting offshore SE Spain (Alboran Sea): imp lications for earthquake hazard assessment in the Southern Iberian Margin. Earth and Planetary Science letters 241, 734-749.

Gutscher, M., Malod, J., Rehault, J., Contrucci, I., Klingelhoefer, F., Mendes-Victor, L., Spalman, W., 2002. Evidence for active subduction beneath Gibraltar. Geology 30 (12), 1071-1074

Hartzell, S., Liu, P., 1996. Calculation of earthquake rupture histories using a hybrid global search algorithm: application to the 1992 Ianders, California, earthquake. Physics of the Earth and Planetary Interiors 95, 79-99.

IGN, 2008. Catálogo sísmico, Instituto Geográfico NacionaL http://www.ign.es/ign/es/ IGN/Sis Cat alogo.jsp.

IGN, 2009a. Base de Datos de Tensor Momento Sísmico, Instituto Geográfico NacionaL http://www.ign.es/ign/es/IGN/SisCalculo.jsp.

IGN, 2009b. Catálogo de Tsunamis en las Costas Españolas. Instituto Geográfico Nacionalwww.ign.es.

Kagan, Y.Y, 2005. Double-coup le earthquake focal mechanism: random rotation and disp lay. Geophysical journal International 163, 1065-1072

Kanamori, H., 1977. The ener gy re lease in great earthquakes. Journal of Geophysical Research 82 (20), 2981-2987.

Kanamori, H, Anderson, D.L, 1975. Theoretical basis of some empirical relations in seismo logy. Bulletin of the Seismo logical Society of America 65 (5), 1073-1095.

Kaverina, A.N., Lander, A.V., Prozorov, A.G., 1996. Global creepex distribution and its relation to earthquake-source geometry and tectonic origin. Geophysical Journal International 125 (1), 249-265.

Keller, J.V.A., Hall, S.H., Dart, C.J., McClay, K.R., 1995. The geometry and evolution of a transpressional strike-slip system: the Carboneras fault, SE Spain. Journal of the Geo logical Society of I ondon 152, 339-351.

Iarouzi ère, F.D., de Bolze, J., Bordet, P., Hernández, J., Montenat, C. Ott d Estevou, P. 1988. The Betic segment of the lithospheric Trans-Alboran shear zone during the Late Miocene. Tectonophysics 152, 41-52.

Liu, P.L.F, Cho, S., Yoon, S.B., Seo, S.N., 1994. Numerical simulations of the 1960 Chilean tsunami propagation and inundation at Hilo, Hawaii, Recent Development in Tsunami Research. In: Tsuchiya, Y., Shutō, N. (Eds.), Tsunami: Progress in Prediction, Disaster Prevention and Warning. : Advances in Natural and Techno logical Hazards Research. Springer, pp. 99-115.

Liu, P.L.-F., Cho, Y.-S., Briggs, M.J., Kanog lu, U., Syno lakis, C.E., 1995. Runup of solitary waves on a circular is land. Journal of Fluid Mechanics 302, 259-285.

Ionergan, L, White, N, 1997. Origin of the Betic-Rif mountain belt. Tectonics 16 (3) 504-522

Iópez Casad o, C, Sanz de Galdeano, C., Mo lina Palacios, S., Henares Romero,J., 2001. The structure of the Alboran Sea: an interpretation from seismo logical and geo logical data. Tectonophysics 338 (2), 79-95.

Iorito, S., Tiberti, M.M., Basili, R., Piatanesi, A, Valensise, G., 2008. Earthquakegenerated tsunamis in the Mediterranean Sea: scenarios of potential threats to Southern Italy. Journal of Geophysical Research 113, B01301. doi:10.1029/ 2007JB004943.

Luis, J.F, 2007. Mirone: a multi-purpose tool for exploring grid data. Computers \& Geosciences 33 ( 1 ), 31-41.

Maestro-González, A., Bárcenas, P., Vázquez, J., del Río, V.D., 2008. The ro le of basement inheritance faults in the recent fracture system of the inner she lf around Alboran Is land, Western Mediterranean. Geo-Marine Ietters 28 (1), 53-64.

Maldonado, A, Campillo, A., Mauffret, A., A lonso, B., Woodside, J., Campos, J., 1992. Alboran Sea late Cenozoic tectonic and stratigraphic evolution. Geo-Marine Letters 12 (2), 179-186.

Mart ínez So lares, J.M., 2003. Sismicidad histórica de la Península Ibérica. Física de la Tierra $15,13-28$.

Mart ínez-Díaz, J.J. 2002. Stress fie ld variation re lated to fault interaction in a reverse oblique-slip fault: the Alhama de Murcia fault, Betic Cordillera, Spain. Tectonophysics 356, 291-305

Masana, E., Mart ínez-Díaz J.J Hernández-Enrile, J.L, Santanach, P, 2004. The A lhama de Murcia fault (SE Spain), a seismogenic fault in a diffuse plate boundary: seismotectonic implications for the Ibero-Magrebian region. Journal of Geophysical Research 109, B01301 doi:10.1029/2002JB002359. mer Méditerranée: un bassin losangique sur la marge nor-a lgérienne. Bulletin de la Société Géo lique de France 8, 1195-1206.

Mau ffret, A., Ammar, A, Gorini, C., Jabour, H., 2007. The Alboran Sea (Western Mediterranean) revisited with a view from the Moroccan Margin. Terra Nova 19, 195-203.

McClusky, S., Reilinger, R., Mahmoud, S., Ben Sari, D., Tealeb, A, 2003. GPS constraints on Africa (Nubia) and Arabia p latemotions. Geophysical Journal International 155, $126-138$.

Meghraoui, M., Morel, J., Andrieux, J., Dahmani, M., 1996. Tectonique plio-quaternaire de la chaine tello-rifaine et de la mer d'Alboran: une zone complexe de convergence continent-continent. Bulletin de la Société Géologique de France $167,141-157$.

Mezcua, J., Rueda, J., 1997. Seismo logical evidence for a de lamination process in the lithosphere under the Alboran Sea. Geophysical Journal International 129 (1), F1-F 8.

Morales, J., Serrano, I, Vidal, F, Torcal, F, 1997. The depth of the earthquake activity in the central Betics (Southern Spain). Geophysical Research Letters 24 (24), 3289-3292

Morales, J., Serrano, I, Jabaloy, A, Galindo Zaldivar, J., Zhao, D., Torcal, F, Vidal, F. González Iodeiro, F., 1999. Active continental subduction beneath the Betic Cordillera and the Alboran Sea. Geology 27 (8), 735-738.

Morel, J., Meghraoui, M., 1996. Gorringe-Alboran-Tell tectonic zone: a transpression system along the Africa-Eurasia plate boundary. Geology 24,755-758

Moreno, X., Masana, E., Gràcia, E., Bartolomé, R, Piqué-Serra, O., 2008. Estudio paleosismológico de la Falla de Carboneras: evidencias tierra-mar de actividad tectónica reciente. Geo-Temas 10, 1035-1038.

Mor ley, C.K., 1993. Discussion of origins of hinter land basins to the Rif-Betic Cordillera and Carpathians. Tectonophysics 226 (1-4), 359-376.

Okada, Y., 1985. Surface deformation due to shear and tensile faults in a half-space. Bulletin of the Seismo logical Society of America 75, 1135-1154

Pineda Ve lasco, A., Giner Sanchez, J., Zazo Carde ña, C, Goy Goy, J.L., Baena Perez, J., Ruiz Arias, F., 1978. MA GNA, Carboneras (1046). Geological Map 1:50.000. Instituto Geológico y Minero de España.

Platt, J.P. Vissers, R.L.M., 1989. Extensional collapse of thickened continental lithosphere: a working hypothesis for the Alboran Sea and Gibraltar arc. Geology $17,540-543$.

Reicherter, K, Hübscher, C, 2007. Evidence for a seafloor rupture of the Carboneras Fault Zone (southern Spain): re lation to the 1522 A lmería earthquake? Journal of Seismo logy $11,15-26$

Rodríguez, J., Martin, A, 1993. Neogene evolution of the Campo de Dalias and the surrounding offshore areas (northeastern Alboran Sea). Geodinamica Acta 6 (4) 255-270.

Royden, L, 1993. Evolution of retreating subduction boundaries formed during continental collision. Tectonics 12 (3), 629-638

Sanz de Galdeano, C. 1990. Geologic evolution of the Betic Cordilleras in the Western Mediterranean, Miocene to the present. Tectonophysics 172 (1-2), 107-119.

Scholz, C.H., 2002. The Mechanics of Earthquakes and Faulting, 2nd Edition. Cambridge University Press, Cambridge.

Seber, D., Barazangi, M. Ibenbrahim, A., Demnati, A, 1996. Geophysical evidence for lithospheric delamination beneath the Alboran Sea and Rif-Betic mountains. Nature 379, 785-790

Sekiguchi, H., Iwata, T., 2002 Rupture process of the 1999 Kocaeli, Turkey, earthquake estimated from strong - motion waveforms. Bulletin of the Seismo logical Society of America 92 (1), 300-311.

Serpelloni, E., Vannucci, G., Pondrelli, S., Argnani, A., Casula, G., Anzidei, M., Baldi, P., Gasperini, P., 2007. Kinematics of the Western Africa-Eurasia plate boundary from focal mechanisms and GPS data. Geophysical Journal International 169,1180-1200.

Shokin, Y.I., Chubarov, L. B., Novikov, V.A., Sudakov, A.N., 1987. Calculations of tsunami travel time charts in the Pacific Ocean. Models, algorithms, techniques, results Science of Tsunami Hazards 5 (2), 85-113.

Soloviev, S.L., Solovieva, O.N., Go, C.N., Kim, K.S., Shchetnikov, N.A., 2000. Tsunamis in the Mediterranean Sea 2000 B.C.-2000 A.D. Advances in Natural and Techno logical Hazards Research. Kluwer Academic Publishers, Dordrecht, The Nether lands.

Stich, D., Ammon, C, Morales, J., 2003. Moment tensor so lutions for small and moderate earthquakes in the Ibero-Maghreb region. Journal of Geophysical Research 108 2002JB002057.

Stich, D., de Lis Mancilla, F., Morales, J., 2005. Crust-mant le coup ling in the Gu lf of Cadiz (SW-Iberia). Geophysical Research Letters 32, L13306. doi:10.1029/ 2005GL023098.

Stich, D., Serpelloni, E., de Lis Mandilla, F., Morales, J., 2006. Kinematics of the IberiaMaghreb plate contact from seismic moment tensors and GPS observations Tectonophysics 426 (3-4), 295-317.

Thiebot, E., Gutscher, M.-A, 2006. The Gibraltar Arc seismogenic zone (part 1): Constraints on a shallow east dipping fault plane source for the 1755 Lisbon earthquake provided by seismic data, gravity and thermal modeling. Tectonophysics 426, 135-152.

Tiberti, M.M., Lorito, S., Basili, R., Kaste lic, V., Piatanesi, A, Valensise, G., 2008. Scenarios of earthquake generated tsunamis for the Italian coast of the Adriatic Sea. Pure and Applied Geophysics 165, 2117-2142

Torne, M., Fernández, M., Comas, M.C., Soto, J.I., 2000. Lithospheric structure beneath the Alboran Basin: results from 3D gravity modeling and tectonic re levance. Journal of Geophysical Research 105 (B2), 3209-3228.

Umut lu, N., Koketsu, K, Mi lkereit, C, 2004. The rupture process during the 1999 Dazce, Turkey, earthquake from joint inversion of teleseismic and strong-motion data. Tectonophysics 391,315-324 
Vegas, R., 1992. Sobre el tipo de deformación distribuida en el contacto entre África y la Península Ibérica. In: Osete, M., Calvo, M. (Eds.), Fisica de la Tierra: Paleomagnetismo y Tectónica en las Cordilleras Beticas, Vol 4. Editorial Complutense, Madrid, pp. 41-56.

Vissers, R.L.M., Platt, J.P., van der Wal, D., 1995. Late orogenic extension of the Betic Cordillera the Alboran Domain: a lithospheric view. Tectonics 14 (4), 786-803.

Wang, X., Liu, P.L.-F, 2005. A numerical investigation of Boumerdes-Zemmouri (Algeria) earthquake and tsunami. Computer Modeling in Engineering and Sciences 10 (2), 171-184

Wang, X., Lu, P.L.-F, 2006. An analysis of 2004 Sumatra earthquake fault plane mechanisms and Indian Ocean tsunami. Journal of Hydraulic Research 44 (2), 147-154.

Watts, A.B., Burov, E.B., 2003. Lithospheric strength and its relationship to the elastic and seismogenic layer thickness. Earth and Planetary Science Letters 213, 113-131.
Watts, A. B., Platt, J.P., Buhl, P, 1993. Tectonic evolution of the Alboran Sea Basin. Basin Research 5, 153-157.

Weijermars, R., 1985. Up lift and subsidence histo ry of the Alboran Basin and a profile of the Alboran Diapir (Westem Mediterranean). Geologie en Mijnbouw 64, 349-356.

Wells, D.L, Coppersmith, K.J., 1994. New empirical relationships among magnitude, rupture length, rupture width, rupture area, and surface displacement. Bulletin of the Seismo logical Society of America 84, 974-1002.

Wessel, P. Smith, W.H.F, 1998. New improved version of Generic Mapping Tools re leased. EOS Transactions of the American Geophysical Union 79 (47), 579.

Woodside, J., Maldonado, A, 1992. Styles of compressional neotectonics in the Eastern A lboran Sea. Geo -Marine Letters 12, 111-116.

Young, C.J., Lay, T., Lynnes, C.S., 1989. Rupture of the 4 February 1976 guatemalan earthquake. Bulletin of the Seismo logical Society of America 79 (3), 670-689. 